九州大学学術情報リポジトリ

Kyushu University Institutional Repository

\title{
Sonolite, a New Manganese Silicate Mineral
}

Yoshinaga, Mayumi

Faculty of Science, Kyushu University

https://doi.org/10.5109/1543583

出版情報：九州大學理學部紀要：Series D, Geology. 14 (1)，pp.1-21，1963-01-30. Faculty of Science, Kyushu University バージョン :

権利関係 : 
Mem. Fac. Sci., Kyushu Univ., Ser. D, Geol., Vol. XIV, No. 1, pp. 1-21, tables 1-10, text-figs. 1-6, pls 1-3, January 25, 1963.

\title{
Sonolite, a New Manganese Silicate Mineral*
}

\author{
By
}

\author{
Mayumi YoshinaGA
}

\begin{abstract}
Sonolite, a new silicate mineral being the manganese analogue of clinohumite, occurs as fine-grained prismatic to anhedral crystals associated with rhodochrosite, galaxite, pyrochroite etc. from Sono, Hanawa, and Kusugi mines and other eight localities. Physical and optical properties of the mineral from Hanawa mine are: dull reddish orange in color; hardness, 5.5 ; specific gravity, 3.82 (meas.) and 3.97 (calc.); colorless in thin section; biaxial negative with $\alpha=1.763, \beta=1.779, \gamma=1.793,(-) 2 \mathrm{~V}=75.5^{\circ}-82^{\circ}$, $\rho>v$, single or lamellae twinning on (001), (001)^X $=9^{\circ}-10^{\circ}$. Monoclinic with $\mathrm{a}_{0}=10.66_{4} \AA \mathrm{b}_{0}=4.88_{2} \AA, c_{0}=14.29_{9} \AA, \beta=100^{\circ} 34^{\prime}$. The chemical formula of sonolite from Hanawa mine is evaluated as $\left(\mathrm{Mn}_{7.80} \mathrm{Fe}_{0.16} \quad \mathrm{Mg}_{1.05} \mathrm{Ca}_{0.16}\right)_{9.17}$

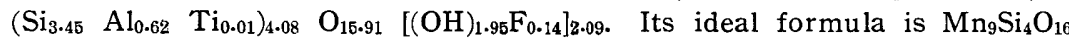
$(\mathrm{OH}, \mathrm{F})_{2}$ or $4 \mathrm{Mn}_{2} \mathrm{SiO}_{4} \cdot \mathrm{Mn}(\mathrm{OH}, \mathrm{F})_{2}$. The mineral from Kusugi mine is also described. The mineral is named after Sono mine where the mineral was first found from. Relations of the mineral to alleghanyite and to humite group are discussed.
\end{abstract}

\section{Introduction}

Alleghanyite is an interesting mineral because it is the manganese analogue of chondrodite in the humite group, and is characterized by the frequent lamellae twin under the microscope. In 1960, during the course of his investigation on alleghanyite and other manganese orthosilicate minerals in Japan, the writer found a dull reddish brown mineral from the 1st level ore body of Sono mine, Kyoto Prefecture and afterwards from many other localities. The optical properties of this mineral are considerably similar to alleghanyite in many respects but distinctive in the maximum symmetrical extinction angle on the lamellae twin-plane.

The results of $\mathrm{X}$-ray studies and chemical analyses indicate this mineral to be a new species, the manganese analogue of clinohumite, and it is proposed to call this mineral sonolite after the locality name where the mineral was first found from.

In this paper a description of sonolite is given in comparison with alleghanyite and with minerals of the humite group.

\footnotetext{
* Received September 20, 1962.
} 


\section{Occurrence and Paragenesis}

In this study, sonolite has been identified in the specimens from ten localities in Japan and from one locality in Formosa. The localities in Japan are shown in Figure 1. The locations of the mines and the kinds of host rocks are listed in Table 1. Most of the manganese mines bearing sonolite are in the cherty formations of the Paleozoic system, and sonolites are usually found intimately associated with rhodochrosite in the rich parts of the ore bodies.

Sonolite is generally pale reddish brown to greyish red brown in color, and occurs as fine-grained aggregates of thin layers in the tephroite or rhodochrosite ore. Modes of occurrence of sonolite and its paragenesis are given in Table 2 . In the specimens from every mine, sonolite was confirmed by the $\mathrm{X}$-ray powder analysis. It is remarkable that the sonolite from Sono and Kusugi mines is closely associated with a small amount of alleghanyite. As recognizable in the mineral parageneses, it is very rare that sonolite associates intimately with hausmannite or braunite. On the contrary, alleghanyite is frequently found in the hausmannite ores.

Microscopic characters of the sonolite-bearing ores from each mine are briefly presented below.

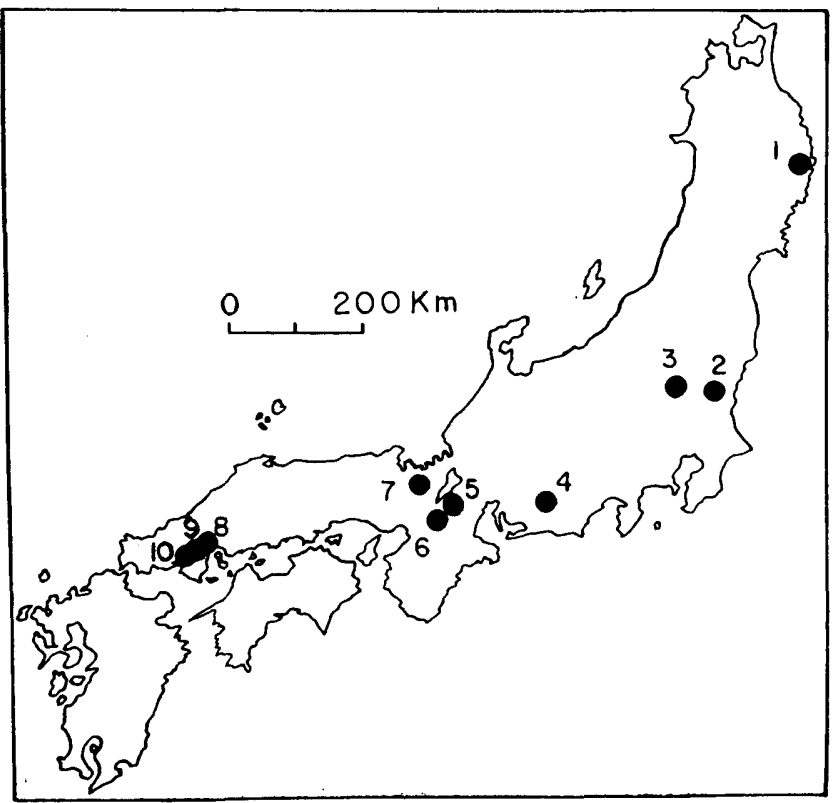

Fig. 1. Locations of the manganese mines, sonolites being found
1. Hanawa mine,
2. Takanominé mine,
3. Kaso mine,
4. Taguchi mine,
5. Ioi mine,
6. Sono mine,
7. Mukaiyama mine,
8. Wagi mine,
9. Takamori mine.
10. Kusugi mine. 
Table 1. Host rocks of the ore deposits and acidic intrusives exposed near the mines

\begin{tabular}{|c|c|c|c|c|}
\hline & Mine & Location & Host rocks & $\begin{array}{l}\text { Acidic intrusives (dis- } \\
\text { tance and direction } \\
\text { from the mine to them) }\end{array}$ \\
\hline 1 & Hanawa & $\begin{array}{l}10 \mathrm{~km} . \mathrm{SW} \text { of Miyako City, } \\
\text { in the east part of Iwate } \\
\text { Prefecture }\end{array}$ & $\begin{array}{l}\text { Cherty formation of } \\
\text { the Paleozoic system }\end{array}$ & $\begin{array}{l}\text { Granodiorite (within } \\
1 \mathrm{~km} . \mathrm{E} \text { ) }\end{array}$ \\
\hline 2 & Takanominé & $\begin{array}{l}25 \mathrm{~km} . \mathrm{NW} \text { of Mito City, } \\
\text { Ibaragi Prefecture }\end{array}$ & $\begin{array}{l}\text { Cherty formation of } \\
\text { the Paleozoic system }\end{array}$ & Granite $(6 \mathrm{~km} . \mathrm{SE})$ \\
\hline 3 & Kaso & $\begin{array}{l}\text { In the Ashio Mountain } \\
\text { District, } 12 \mathrm{~km} \text {. NW of } \\
\text { Kanuma City, Tochigi } \\
\text { Prefecture }\end{array}$ & $\begin{array}{l}\text { Cherty formation of } \\
\text { the Paleozoic system }\end{array}$ & $\begin{array}{l}\text { Granodiorite }(3 \mathrm{~km} . \mathrm{N}) \text {, } \\
\text { quartz porphyry }(1.5 \\
\mathrm{km} . \mathrm{N} \text { and } \mathrm{NW})\end{array}$ \\
\hline 4 & Taguchi & $\begin{array}{l}\text { In the Dando Mountain } \\
\text { District, } 24 \mathrm{~km} \text {. NE of } \\
\text { Toyohashi City, Aichi } \\
\text { Prefecture }\end{array}$ & $\begin{array}{l}\text { Quartz schist, a } \\
\text { member of Ryoké } \\
\text { metamorphic rocks }\end{array}$ & $\begin{array}{l}\text { Hornblende-biotite } \\
\text { granite }(1 \mathrm{~km} . \mathrm{SE}), \\
\text { muscovite-biotite } \\
\text { granite }(2 \mathrm{~km} . \mathrm{NW})\end{array}$ \\
\hline 5 & Ioi & $\begin{array}{l}10 \mathrm{~km} . \mathrm{E} \text { of Otsu City, on } \\
\text { the south side of the lake } \\
\text { of Biwa }\end{array}$ & $\begin{array}{l}\text { Formation comprising } \\
\text { chert and sandyslate } \\
\text { of the Paleozoic system }\end{array}$ & $\begin{array}{l}\text { Biotite granite }(4 \mathrm{~km} . \mathrm{S}), \\
\text { granite porphyry }(2 \mathrm{~km} . \mathrm{E}) \text {, } \\
\text { quartz porphyry }(500 \mathrm{~m} . \mathrm{N})\end{array}$ \\
\hline 6 & Sono & $23 \mathrm{~km}$. SE of Kyoto City & $\begin{array}{l}\text { Slaty formation of the } \\
\text { Paleozoic system }\end{array}$ & Granite $(4 \mathrm{~km} . \mathrm{SW})$ \\
\hline 7 & Mukaiyama & $\begin{array}{l}\text { In the Tamba Plateau, } 38 \\
\mathrm{~km} \text {. NW of Kyoto City }\end{array}$ & $\begin{array}{l}\text { Cherty formation of } \\
\text { the Paleozoic system }\end{array}$ & ? \\
\hline 8 & Wagi & $\begin{array}{l}4 \mathrm{~km} . \mathrm{N} \text { of Iwakuni City, } \\
\text { Yamaguchi Prefecture }\end{array}$ & $\begin{array}{l}\text { Cherty formation of } \\
\text { the Paleozoic system }\end{array}$ & $\begin{array}{l}\text { Biotite granite }(1 \mathrm{~km} . \\
\mathrm{E})\end{array}$ \\
\hline 9 & Takamori & $\begin{array}{l}13 \mathrm{~km} . \text { W of Iwakuni City, } \\
\text { Yamaguchi Prefecture }\end{array}$ & $\begin{array}{l}\text { Cherty formation of } \\
\text { the Paleozoic system }\end{array}$ & $\begin{array}{l}\text { Biotite granite }(2 \mathrm{~km} . \\
\mathrm{S} \text { and } \mathrm{NE})\end{array}$ \\
\hline 10 & Kusugi & $\begin{array}{l}19 \mathrm{~km} . \mathrm{W} \text { of Iwakuni City, } \\
\text { Yamaguchi Prefecture }\end{array}$ & $\begin{array}{l}\text { Cherty formation of } \\
\text { the Paleozoic system }\end{array}$ & $\begin{array}{l}\text { Biotite granite }(500 \mathrm{~m} . \\
\text { S) }\end{array}$ \\
\hline 11 & Suao & $\begin{array}{l}\text { Near Suao, Northern } \\
\text { Formosa }\end{array}$ & The Tananao schist & \\
\hline
\end{tabular}

1. 岩手県宮古市花輸花輪鉝山

3. 杤木県鹿沼市上久我加蘇鉝山

5. 滋賀県栗太郡栗東町五百井鉣山

7. 京都府北桑田郡美山町向山鈗山

9. 山口県玫珂郡周東町高森鉣山

11. 台湾省蘇澳鎮西赗山蘇澳鉱山
2. 茨城県東茨城郡御前山村鷹峰鉱山

4. 愛知県北設楽郡設楽町因口鈶山

6. 京都府相楽郡和束町園鉱山

8. 山口県玫珂郡和木村和木鉣山

10. 山口辱玖珂郡周東町久杉鉱山

\section{Hanawa mine, Iwaté Prefecture}

Round or subhedral prismatic crystals of sonolite, associated with bementite and a small amount of pyrochroite, are seen disseminated in the recrystallized rhodochrosite showing mosaic texture (Plate 1, Figures 1 and 2). The twinning with a few lamellae is common, but a single twinned type is also present. There are many faint veinlets of bementite of a later stage. Tephroite closely associated with sonolite shows corroded grains with irregular outlines, and it is enclosed in 
Table 2. Occurrence of sonolite and its paragenesis

\begin{tabular}{|c|c|c|c|}
\hline & Mine & Occurrence & Associated minerals \\
\hline 1 & Hanawa & $\begin{array}{l}\text { As irregular aggregates } \\
\text { In tephroite ore }\end{array}$ & $\begin{array}{l}\text { Rhodochrosite, tephroite, bementite and } \\
\text { pyrochroite }\end{array}$ \\
\hline 2 & Takanominé & $\begin{array}{l}\text { As bands } \\
\text { In banded rhodochrosite ore }\end{array}$ & Rhodochrosite, tephroite and spessartine \\
\hline 3 & Kaso & $\begin{array}{l}\text { As bands } \\
\text { In dark brownish grey banded ore }\end{array}$ & $\begin{array}{l}\text { Rhodochrosite, manganosite, pyrochroite } \\
\text { and galaxite }\end{array}$ \\
\hline 4 & Taguchi & $\begin{array}{l}\text { In saccharoidal rhodochrosite } \\
\text { ore, being somewhat schistose }\end{array}$ & $\begin{array}{l}\text { Rhodochrosite, pyrochroite, galaxite and } \\
\text { alabandite }\end{array}$ \\
\hline 5 & Ioi & $\begin{array}{l}\text { As bands } \\
\text { In dark brownish grey banded ore }\end{array}$ & $\begin{array}{l}\text { Rhodochrosite, tephroite, manganosite, } \\
\text { pyrochroite and galaxite }\end{array}$ \\
\hline 6 & Sono & $\begin{array}{l}\text { As irregular aggregates } \\
\text { In tephroite-rhodonite ore }\end{array}$ & Rhodochrosite, tephroite and alleghanyite \\
\hline 7 & Mukaiyama & $\begin{array}{l}\text { As lenticular aggregates } \\
\text { In banded rhodochrosite ore }\end{array}$ & $\begin{array}{l}\text { Rhodochrosite, tephroite, rhodonite and } \\
\text { bementite }\end{array}$ \\
\hline 8 & Wagi & $\begin{array}{l}\text { As bands } \\
\text { In dark brownish grey banded ore }\end{array}$ & Rhodochrosite, pyrochroite and alabandite \\
\hline 9 & Takamori & $\begin{array}{l}\text { As lenticular aggregates } \\
\text { In rhodochrosite ore }\end{array}$ & Rhodochrosite and bementite \\
\hline 10 & Kusugi & $\begin{array}{l}\text { As irregular aggregates } \\
\text { In tephroite ore }\end{array}$ & $\begin{array}{l}\text { Rhodochrosite, tephroite, galaxite, } \\
\text { pyrochroite, alabandite and alleghanyite }\end{array}$ \\
\hline 11 & Suao & $\begin{array}{l}\text { As irregular aggregates } \\
\text { In rhodonite ore }\end{array}$ & Rhodochrosite and spessartine \\
\hline
\end{tabular}

the mosaic of rhodochrosite and sonolite. Tephroite is usually olive green in color and in thin section very pale yellowish green.

\section{Takanominé mine, Ibaragi Prefecture}

Sonolite is found associated with rhodochrosite, tephroite and a small amount of spessartine in the Kawakami adit of this mine. Under the microscope, sonolite and the associated minerals make bands of 2 to 10 milimeters in width. Sonolite band often shows parallel intergrowth of long prismatic crystals perpendicular to the band, whereas tephroite band is always composed of aggregates of round crystals. The twinning with a few lamellae is common. In the Ofuji adit, about 4.5 kilometers south of the Kawakami adit, alleghanyite occurs with hausmannite, manganosite and rhodochrosite.

\section{Kaso mine, Tochigi Prefecture}

Kaso mine is one of the largest manganese mines in Japan. The detailed studies on the minerals from this mine were made by Yoshimura $(1938,1939)$. Sonolite is found in the banded ore occuring from the east part of the minus 14th level of this mine. Under the microscope, sonolite occurs as subhedral long prismatic 
crystals with rhodochrosite, manganosite, pyrochroite and galaxite. The lamellae or single twinning is common. The associated manganosite is emerald green in color and often rimmed with the fibrous pyrochroite. In the most parts, manganosite is formed among the aggregates of sonolite crystals. Radial developments of partings are often observed around manganosite grains as shown in Plate 1, Figure 3, and this fact suggests that manganosite was formed after the crystallization of sonolite. Alleghanyite is also found in the grey manganese carbonate ores from this mine. According to Yoshimura $(1938,1939)$, it occurs as tiny crystals showing the characteristic twinning closely associated with alabandite.

\section{Taguchi mine, Aichi Prefecture}

Taguchi mine is rather small in scale, but is famous for the occurrence of a great many kinds of manganese minerals. In the $3 \mathrm{rd}$ level adit of the mine sonolite was found abundantly in the saccharoidal carbonate ore, which is somewhat schistose, and disseminated with brownish black spots originating from pyrochroite. Under the microscope the carbonate ore is composed of coarse-grained recrystallized rhodochrosite enclosing round crystals of sonolite, aggregates of fibrous pyrochroite, and small amounts of galaxite and alabandite grains. Rhodochrosite shows the mosaic texture composed of the grains elongated nearly parallel with the schistosity of the ore. The single twinning is commonly observed on sonolite. The composite twin is rarely present, but the twin-law could not be determined. Parting is common on the sonolite grain, but rare on rhodochrosite as shown in Plate 1, Figure 4. Although alleghanyite was reported previously from this mine*, it has not been found in any specimens during this study.

\section{Ioi mine, Shiga Prefecture}

The descriptions of the manganese ore deposits of Ioi mine were given by SHIROzU (1949a, 1949b) with mineralogical studies of hausmannite from this mine. Sonolite is abundant in the dark brownish grey banded ore occuring from the $115 \mathrm{~m}$. level of the eastern ore body. In thin section, subhedral short prismatic to anhedral crystals of sonolite form a mosaic texture accompanied by tephroite, rhodochrosite, manganosite, pyrochroite, and galaxite. Most of sonolite in this mine show usually the single twinning, and the lamellae twinned type is rare. Associated manganosite grains are often rimmed with the fibrous pyrochroite. Aggregates of tephroite grains form bands ranging 2 to 5 milimeters in width. Alleghanyite is reported by SHirozu (1949a, 1949b) and by LeE (1955) from this mine. The writer has re-examined the thin sections studied by SHIROzU with a result that at least a part of them is distinctly sonolite.

\footnotetext{
* According to an unpublished paper by $\mathrm{F}$. Hirowatari.
} 


\section{Sono mine, Kyoto Prefecture}

In the 1st level adit of this mine, sonolite occurs as fine-grained masses in the tephroite-rich part of the tephroite-rhodonite ore. A polished hand specimen of the sonolite-bearing ore from Sono mine is shown in Plate 2, Figure 5. Rhodochrosite is found along the boundary between tephroite and rhodonite. The ore is traversed by a few veinlets of a later stage, composed of pyroxmangite and neotocite. Finegrained rhodochrosite is found along the veinlets. Under the microscope, sonolite
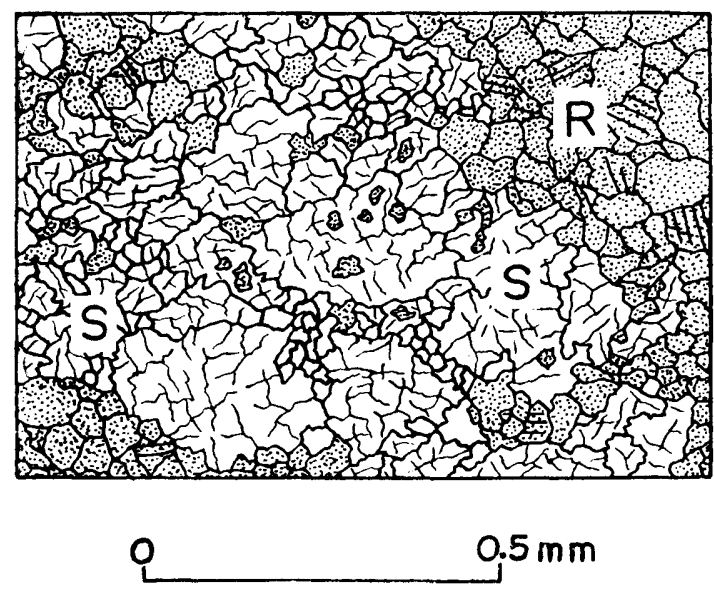

Fig. 2. Sketch of thin section of sonolite-rich part in tephroite-rhodonite ore from the 1st adit of Sono mine, Kyoto Prefecture

$\mathrm{S}$ : sonolite, $\mathrm{R}$ : rhodochrosite. is intimately associated with the mosaic of rhodochrosite, and shows generally no definite crystal form as shown in Figure 2. The lamellae twinning is common. Sometimes aggregates of long prismatic crystals are observable. A small amount of alleghanyite was recognized associated with sonolite. The presence of alleghanyite was also confirmed by $\mathrm{X}$-ray diffraction. In the Hirata adit of this mine, alleghanyite occurs as reddish brown masses in the rhodochrosite ores, but it is not accompanied by sonolite.

\section{Mukaiyama mine, Kyoto Prefecture}

At the 2nd level of the Kuritani ore body, sonolite is found as a small compact lens-shaped mass in the banded carbonate ore on the hanging wall side. Under the microscope, sonolite forms extremely fine-grained aggregates of anhedral crystals closely associated with rhodochrosite. Twinned crystals are rare, though the lamellae twinning is observable. A small amount of tephroite, rhodonite and bementite are also found among them. In the black chert, a few centimeters above this lens, there
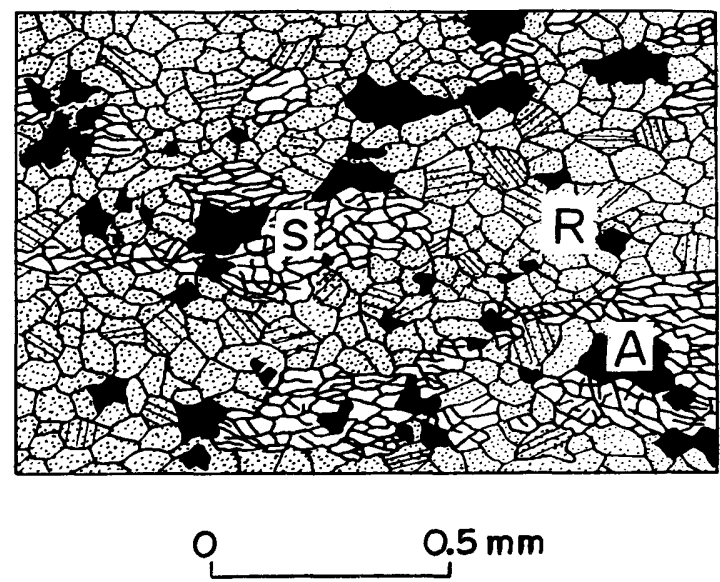

Fig. 3. Sketch of thin section of sonolite-bearing banded ore from Wagi mine, Yamaguchi Prefecture S: sonolite, R: rhodochrosite, A: alabandite. 
are small lenses of alleghanyite surrounded by thin layers of rhodochrosite. Cores of the alleghanyite lenses are manganosite. From the same ore body, aggregates of alleghanyite were found associated with tephroite and rhodochrosite. Some mineralogical properties of this mineral are given in Chapter VIII.

\section{Wagi mine, Yamaguchi Prefecture}

Sonolite is found abundantly as anhedral grains with alabandite in the mosaic of rhodochrosite as shown in Figure 3. Parting is common on the sonolite crystals. The twinning with a few lamellae is commonly observed.

\section{Takamori mine, Yamaguchi Prefecture}

In the Ohira ore body of this mine, sonolite is found as small lenticular aggregates in the finegrained rhodochrosite layers on the hanging wall side. Under the microscope, the lenticular part is composed of anhedral crystals of sonolite accompanied by recrystallized rhodochrosite (Figure 4). The lamellae twinning is observable on sonolite, but twinned crystals are rare. Considerable amo. unts of bementite and neotocite are also present.

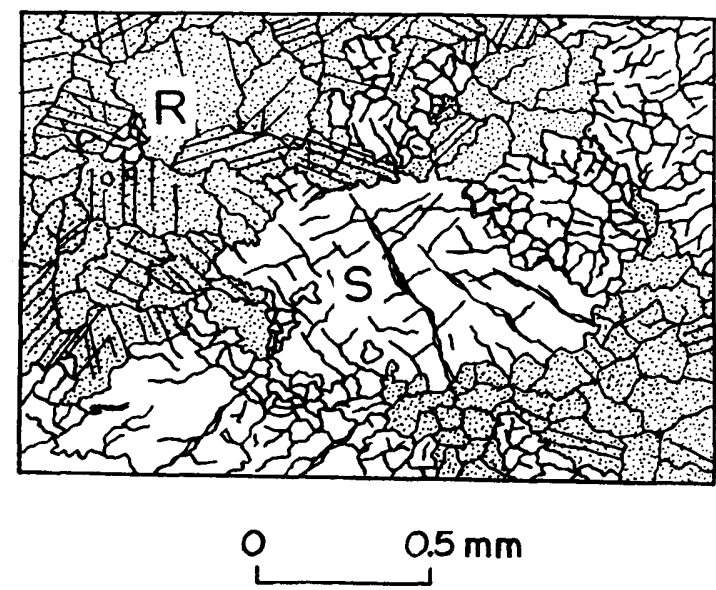

Fig. 4. Sketch of thin section of sonolite-rich part in rhodochrosite ore from Takamori mine, Yamaguchi Prefecture S: sonolite, $\mathrm{R}$ : rhodochrosite.

\section{Kusugi mine, Yamaguchi Prefecture}

Sonolite is found from the Zomeki ore body of this mine, and occurs as dense aggregates closely associated with rhodochrosite in the tephroite ore. Under the microscope the aggregates are composed of the sutured mosaic of sonolite and rhodochrosite, accompanied by minute round grains of galaxite, corroded grains of alabandite, and fibrous pyrochroite (Plate 2, Figure 6 and 7). The lamellae twinning is common on sonolite crystals. Subhedral prismatic crystals of alleghanyite are also found closely associated with alabandite. Alleghanyite in this ore body is reported by Yoshimura and Momor (1961). It is found in the tephroite-rhodonite ore, and is characterized by the following distinct pleochroism; $\mathrm{X}=$ wine yellow, $\mathrm{Y}=$ colorless, $Z=$ colorless.

\section{Suao mine, Suao, Formosa}

In a rhodonite ore of Suao mine, being sent from Mr. F. C. Chen to Prof. T. Yoshimura, a small amount of sonolite was found intimately associated with rhodo- 
chrosite.

Most of the deposits bearing sonolite are located in the Paleozoic formations of the granite regions. The kinds of granitic rocks and distance from the mine to them are also listed in Table 1. Although no exposure of granitic rocks is found near Mukaiyama mine, two tungsten mines are working nearby Wachi Town about 8 kilometers west of this mine, and it is supposed that there may be hidden masses of acidic intrusives in this area.

As described above, in most mines the rhodochrosite associated with sonolite shows the mosaic texture under the microscope, and is considered to be the recrystallization product due to the thermal metamorphism or the metasomatism. The formation of sonolite, therefore, seems to be related to the metasomatism of acidic intrusive accompanied by fluorine.

Associated minerals with sonolite correspond to magnesium minerals in metasomatized dolomitic limestones and dolomites, as shown in the follows:

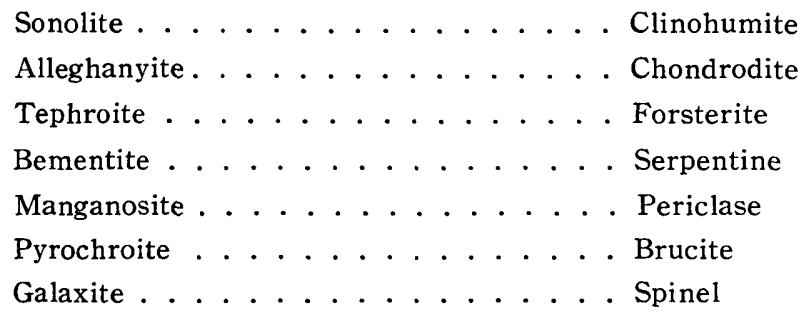

Coruudum is said to associate frequently with clinohumite, but it is not found in the manganese ore deposits.

\section{Size and Shape of Sonolite}

In most localities, sonolite crystals are generally small, less than 0.5 milimeter in length. Crystallographic characters of the sonolite crystal cannot be easily determined. Under the microscope, however, prismatic crystal sections with one straight edge are often observed on the specimens from several mines, e.g. Hanawa, Takanominé, Kaso and Sono mines, although round or anhedral crystals are common in the other localities. This straight edge is always parallel to the twin-lamellae as shown in Plate 3, Figures 8 and 9. If sonolite is the manganese analogue of clinohumite, this edge may be the trace of the (001) face. Sometimes short edges, presumably being traces of (101) and (100) faces, are also observed. On one crystal section from Hanawa mine, the angle $(001)^{\wedge}(101)$ was measured to be approximately $77^{\circ}$. The corresponding angle of clinohumite is $79^{\circ} 111 / 2^{\prime}$ (KöPPEN, 1950). According to Rogers (1935), the angle $(001)^{\wedge}(101)$ of alleghanyite is about $69^{\circ}$, while the corresponding one of the chondrodite is $70^{\circ} 561 / 2^{\prime}$. Most of the subhedral crystal sections of sonolite are elongated parallel with the trace of (001) face, 
and show short or long prismatic habit. On the contrary, alleghanyite crystals are usually equidimensional with a tendency toward tabular habit.

\section{Preparation}

Besides sonolite, the specimens from most localities include large amounts of impurities such as rhodochrosite, pyrochroite, galaxite. Therefore, it is very difficult to prepare the materials sufficiently pure for experiments. Since the specimens from Hanawa mine and Kusugi mine were comparatively pure, they were chosen as the main materials to be investigated in detail and were carefully separated by hand-picking under a magnifying glass.

\section{Physical and Optical Properties}

In hand specimen sonolite is dull reddish organge to pale reddish brown in color. When tinged pinkish, it resembles alleghanyite very closely. In thin section sonolite is translucent, colorless, and not pleochroic. The specific gravities measured with a pycnometer are 3.82 (Hanawa) and 3.87 (Kusugi); the calculated values from the chemical compositions and the unit cell dimensions described later are 3.97 (Hanawa) and 4.03 (Kusugi). The hardness is 5.5 on Mohs' scale.

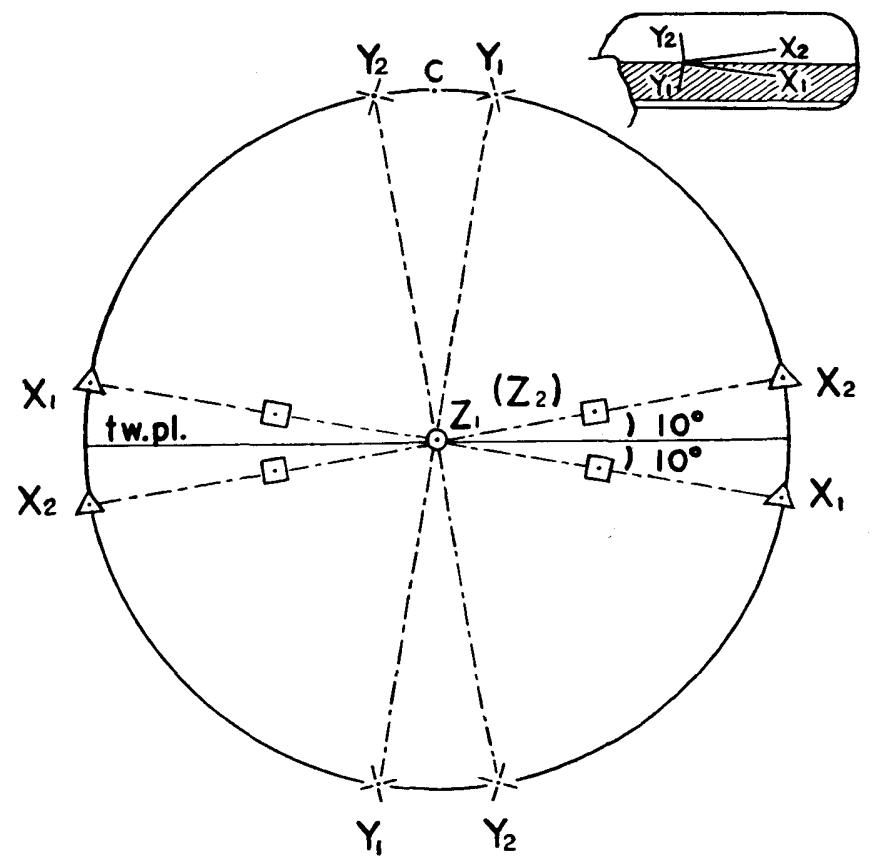

Fig. 5. Stereographic projection of the optical orientation and the trace of twin-plane of a sonolite flake from Hanawa mine The squares indicate the optic axes. 
The refractive indices measured by immersion method and the optic axial angles are :

$$
\begin{array}{llll}
\alpha=1.763, & \beta=1.779, & \gamma=1.793, & (-) 2 \mathrm{~V}=75.5^{\circ}-82^{\circ} \text { (Hanawa). } \\
\alpha=1.763, & \beta=1.779, & \gamma=1.792, & (-) 2 \mathrm{~V}=70^{\circ}-73^{\circ} \text { (Kusugi). }
\end{array}
$$

Dispersion is $\rho>v$, weak. The lamellae or single twinning is common, and resembles those of alleghanyite, chondrodite, and clinohumite; the twin-lamellaes are generally broad but sometimes as numerous as in the plagioclase section (Plate 3, Figures $8,9,10,11$ and 12). The extinction angles measured on the lamellae or single twinning normal to $Z$ are $9^{\circ}-10^{\circ}$ (Hanawa) and $10^{\circ}$ (Kusugi). A stereographic projection of the optical orientation for a twinned flake from Hanawa mine is shown in Figure 6. The optical orientation of sonolite and the relation to the twin-plane correspond closely to those of clinohumite except that the latter mineral is optically positive. It seems probable, therefore, that the lamellae or single twin-plane of sonolite is parallel to (001) face.

\section{X-ray Studies}

The X-ray powder diffraction patterns were taken with a Shimazu X-ray diffractometer under the following operating conditions: X-ray radiation, $\mathrm{Mn}$-filtered Fe radiation ( $\lambda=1.93597 \AA$ for $\left.\mathrm{K} \alpha_{1}\right)$; scanning speed, $1 / 2^{\circ} / \mathrm{min}$.; chart speed, $10 \mathrm{~mm} /$ min.; full scale, 1000 counts/sec.; time constant, 5 sec.; receiving slit, $0.4 \mathrm{~mm}$.

The readings of diffraction angles were corrected with an internal standard of silicon. The powder data obtained for sonolite from Sono mine, Hanawa mine and Kusugi mine are listed in Table 3. The diagram of the powder pattern of sonolite from Kusugi mine is given in the upper part of Figure 6 together with that of clinohumite from Finland (Saнама, 1953) for comparison. The structual analogue of sonolite to clinohumite is evident, but the sonolite pattern shows larger $d$-spacings corresponding to a larger unit cell than those of clinohumite. For most lines of sonolite there are corresponding lines of clinohumite except differences in intensities. By using the unit cell dimensions given by TAYLOR and WEsT $(1928,1929)$, the data for clinohumite by SAHAMA were indexed. With help of the results obtained for clinohumite, the indexing of the reflections and the calculations of the unit cell dimensions for sonolite were carried out on the assumption that these two minerals are isostructural. The pattern of the mineral from Sono mine is so typical in spite of including rhodochrosite impurity, that the data were very useful for indexing. The unit cell dimensions obtained for three sonolites are as follows:

$$
\begin{array}{lllll}
\mathrm{a}_{0}=10.66_{8} \AA, & \mathrm{b}_{0}=4.88_{8} \AA, & \mathrm{c}_{0}=14.33_{3} \AA, & \beta=100^{\circ} 34^{\prime} & \text { (Sono). } \\
\mathrm{a}_{0}=10.66_{4} \AA, & \mathrm{b}_{0}=4.88_{2} \AA, & \mathrm{c}_{0}=14.29_{9} \AA, & \beta=100^{\circ} 34^{\prime} & \text { (Hanawa). } \\
\mathrm{a}_{0}=10.66_{0} \AA, & \mathrm{b}_{0}=4.87_{8} \AA, & \mathrm{c}_{0}=14.29_{6} \AA, & \beta=100^{\circ} 34^{\prime} & \text { (Kusugi). }
\end{array}
$$


Table 3. X-ray powder data for sonolite

\begin{tabular}{|c|c|c|c|c|c|c|c|c|c|c|c|c|}
\hline \multirow[b]{2}{*}{ hkl } & \multicolumn{4}{|c|}{1} & \multicolumn{4}{|c|}{2} & \multicolumn{4}{|c|}{3} \\
\hline & Q calc. & Q obs. & d obs.(文) & I & Q calc. & Q obs. & d obs. $(\AA)$ & I & Q calc. & Q obs. & d obs. (§) & I \\
\hline $\begin{array}{l}200 \\
20 \overline{1}\end{array}$ & $\left.\begin{array}{l}0.0364 \\
0.0364\end{array}\right\}$ & 0.0364 & 5.243 & 1.1 & $\left.\begin{array}{l}0.0364 \\
0.0365\end{array}\right\}$ & 0.0363 & 5.248 & 1.3 & $\left.\begin{array}{l}0.0364 \\
0.0365\end{array}\right\}$ & 0.0364 & 5.240 & 1.2 \\
\hline 003 & 0.0453 & 0.0455 & 4.688 & 0.5 & & & & & 0.0456 & 0.0456 & 4.683 & 0.3 \\
\hline 201 & 0.0464 & & & & $0.0464)$ & & & & $0.0465)$ & & & \\
\hline $20 \overline{2}$ & 0.0466 & 0.0465 & 4.637 & 0.8 & 0.0467 & 0.0464 & 4.641 & 1.2 & $0.0467\}$ & 0.0465 & 4.637 & 0.8 \\
\hline 011 & 0.0469 & & & & 0.0470 & & & & 0.0471 & & & \\
\hline 110 & 0.0510 & 0.0510 & 4.427 & 0.4 & & & & & & & & \\
\hline 012 & 0.0620 & 0.0622 & 4.011 & 0.7 & 0.0622 & 0.0622 & 4.011 & 1.0 & 0.0623 & 0.0624 & 4.004 & 0.7 \\
\hline $11 \overline{2}$ & 0.0661 & & & & 0.0663 & & & & 0.0664 & & & \\
\hline 202 & 0.0664 & 0.0664 & 3.882 & 1.5 & 0.0666 & 0.0665 & 3.879 & 1.5 & 0.0666 & 0.0667 & 3.871 & 1.5 \\
\hline $20 \overline{3}$ & 0.0668 & & & & 0.0670 & & & & $0.0671 \mid$ & & & \\
\hline 112 & 0.0761 & 0.0761 & 3.626 & 2.8 & 0.0763 & 0.0762 & 3.622 & 4.0 & 0.0764 & 0.0764 & 3.618 & 3.6 \\
\hline 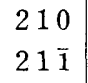 & $\left.\begin{array}{l}0.0782 \\
0.0783\end{array}\right\}$ & 0.0782 & 3.575 & 0.9 & $\left\{\begin{array}{l}0.0784 \\
0.0784\end{array}\right\}$ & 0.0781 & 3.578 & 1.7 & $\left.\begin{array}{l}0.0785 \\
0.0785\end{array}\right\}$ & 0.0786 & 3.568 & 1.1 \\
\hline 004 & 0.0806 & 0.0808 & 3.519 & 1.1 & 0.0810 & 0.0810 & 3.514 & 0.9 & 0.0810 & 0.0811 & 3.512 & 0.8 \\
\hline $\begin{array}{l}21 \overline{2} \\
11 \overline{3}\end{array}$ & $\left.\begin{array}{l}0.0885 \\
0.0889\end{array}\right\}$ & 0.0889 & 3.353 & 2.1 & $\left\{\begin{array}{l}0.0886 \\
0.0891\end{array}\right\}$ & 0.0891 & 3.351 & 2.3 & $\left.\begin{array}{l}0.0887 \\
0.0892\end{array}\right\}$ & 0.0893 & 3.346 & 2.8 \\
\hline $\begin{array}{l}212 \\
21 \overline{3}\end{array}$ & $\left\{\begin{array}{l}0.1083 \\
0.1087\end{array}\right\}$ & 0.1086 & 3.035 & 0.3 & $\left.\begin{array}{l}0.1086 \\
0.1090\end{array}\right\}$ & 0.1088 & 3.031 & 0.7 & $\left.\begin{array}{l}0.1087 \\
0.1091\end{array}\right\}$ & 0.1091 & 3.027 & 0.6 \\
\hline $\begin{array}{l}31 \overline{1} \\
11 \overline{4}\end{array}$ & $\left\{\begin{array}{l}0.1213 \\
0.1216\end{array}\right\}$ & 0.1213 & 2.871 & 5.4 & $\left\{\begin{array}{l}0.1214 \\
0.1221\end{array}\right\}$ & 0.1213 & 2.871 & 10 & $\left.\begin{array}{l}0.1216 \\
0.1222\end{array}\right\}$ & 0.1217 & 2.867 & 10 \\
\hline 310 & 0.1237 & 0.1235 & $2.845^{*}$ & 10 & 0.1238 & 0.1232 & 2.849 & 4.3 & 0.1240 & 0.1237 & 2.843 & 7.0 \\
\hline 005 & 0.1259 & 0.1259 & 2.818 & 1.8 & 0.1265 & 0.1264 & 2.813 & 1.2 & 0.1266 & 0.1269 & 2.807 & 1.1 \\
\hline $\begin{array}{lll}3 & 1 & 1 \\
2 & 0 & 4\end{array}$ & $\left.\begin{array}{l}0.1362 \\
0.1368\end{array}\right\}$ & 0.1365 & 2.707 & 1.9 & $\left.\begin{array}{l}0.1364 \\
0.1373\end{array}\right\}$ & 0.1366 & 2.706 & 2.5 & $\left.\begin{array}{l}0.1365 \\
0.1374\end{array}\right\}$ & 0.1372 & 2.700 & 2.3 \\
\hline $20 \overline{5}$ & 0.1375 & 0.1372 & 2.700 & 1.7 & 0.1380 & 0.1376 & 2.696 & 2.4 & & & & \\
\hline 114 & 0.1415 & 0.1416 & 2.658 & 3.3 & 0.1420 & 0.1420 & 2.654 & 5.0 & 0.1421 & 0.1423 & 2.651 & 4.7 \\
\hline $31 \overline{3}$ & 0.1467 & 0.1466 & 2.612 & 2.8 & 0.1470 & 0.1468 & 2.610 & 5.2 & 0.1471 & 0.1471 & 2.607 & 3.6 \\
\hline 312 & 0.1587 & 0.1584 & 2.512 & 2.2 & 0.1590 & 0.1589 & 2.509 & 2.6 & 0.1592 & 0.1591 & 2.507 & 2.1 \\
\hline 401 & 0.1605 & 0.1604 & 2.4967 & 1.2 & 0.1606 & 0.1603 & 2.4979 & 1.8 & 0.1607 & 0.1607 & 2.4943 & 1.6 \\
\hline $11 \overline{5}$ & 0.1645 & 0.1647 & 2.4642 & 2.6 & 0.1651 & 0.1651 & 2.4612 & 3.4 & 0.1653 & 0.1652 & 2.4602 & 2.5 \\
\hline $\begin{array}{l}020 \\
015\end{array}$ & $\left.\begin{array}{l}0.1675 \\
0.1678\end{array}\right\}$ & 0.1674 & 2.4440 & 0.7 & $\left\{\begin{array}{l}0.1678 \\
0.1685\end{array}\right\}$ & 0.1678 & 2.4410 & 0.9 & $\left\{\begin{array}{l}0.1681 \\
0.1686\end{array}\right\}$ & 0.1681 & 2.4388 & 0.6 \\
\hline 120 & 0.1766 & 0.1763 & 2.3813 & 0.7 & & & & & 0.1772 & 0.1771 & 2.3762 & 0.8 \\
\hline $\begin{array}{l}12 \overline{1} \\
21 \overline{5}\end{array}$ & $\left.\begin{array}{l}0.1791 \\
0.1793\end{array}\right\}$ & 0.1792 & 2.3618 & 2.0 & $\left\{\begin{array}{l}0.1795 \\
0.1800\end{array}\right\}$ & 0.1795 & 2.3598 & 2.5 & $\left.\begin{array}{l}0.1798 \\
0.1801\end{array}\right\}$ & 0.1799 & 2.3582 & 2.4 \\
\hline $41 \overline{1}$ & $0.182 \bar{\jmath}$ & 0.1821 & 2.3436 & 1.7 & 0.1826 & 0.1824 & 2.3414 & 2.1 & 0.1828 & 0.1826 & 2.3401 & 2.3 \\
\hline 115 & 0.1893 & 0.1891 & 2.2995 & 0.4 & & & & & 0.1902 & 0.1904 & 2.2922 & 0.6 \\
\hline $\begin{array}{l}313 \\
12 \overline{2}\end{array}$ & $\left.\begin{array}{l}0.1914 \\
0.1918\end{array}\right\}$ & 0.1914 & 2.2857 & 0.5 & & & & & $\left.\begin{array}{l}0.1920 \\
0.1925\end{array}\right\}$ & 0.1925 & 2.2794 & 0.6 \\
\hline 122 & 0.2017 & O 2010 & 22253 & 04 & & & & & $0.2024\}$ & 02030 & & \\
\hline 411 & $0.2023\}$ & 0.2019 & 2.2253 & 0.4 & & & & & $0.2027\}$ & 0.2030 & 2.2197 & 0.7 \\
\hline 405 & 0.2218 & 0.2218 & 2.1234 & 0.3 & & & & & & & & \\
\hline $22 \overline{5}$ & 0.3050 & 0.3049 & 1.8112 & 4.2 & 0.3059 & 0.3058 & 1.8083 & 5.5 & 0.3062 & 0.3061 & 1.8075 & 4.1 \\
\hline 414 & 0.3077 & 0.3075 & 1.8033 & 1.9 & & & & & 0.3086 & 0.3083 & 1.8011 & 2.2 \\
\hline 125 & 0.3149 & 0.3158 & 1.7794 & 0.4 & & & & & 0.3162 & 0.3170 & 1.7761 & 1.0 \\
\hline 405 & 0.3211 & 0.3215 & 1.7636 & 0.8 & & & & & & & & \\
\hline 600 & 0.3273 & 0.3274 & 1.7478 & 1.4 & & & & & & & & \\
\hline $\begin{array}{l}421 \\
60 \overline{3}\end{array}$ & $\left\{\begin{array}{l}0.3279 \\
0.3280\end{array}\right\}$ & 0.3280 & 1.7460 & 1.3 & $\left\{\begin{array}{l}0.3284 \\
0.3283\end{array}\right\}$ & 0.3287 & 1.7443 & 0.9 & $\left.\begin{array}{l}0.3288 \\
0.3286\end{array}\right\}$ & 0.3286 & 1.7444 & 1.0 \\
\hline 601 & 0.3473 & 0.3474 & 1.6967 & 0.8 & 0.3476 & 0.3477 & 1.6960 & 1.0 & 0.3478 & 0.3481 & 1.6950 & 0.8 \\
\hline 026 & 0.3488 & 0.3490 & 1.6927 & 1.0 & & & & & 0.3504 & 0.3508 & 1.6883 & 1.0 \\
\hline 316 & 0.3497 & 0.3505 & 1.6889 & 1.1 & & & & & & & & \\
\hline $51 \overline{6}$ & 0.3761 & 0.3763 & 1.6312 & 0.3 & & & & & 0.3772 & 0.3765 & 1.6297 & 0.3 \\
\hline $\begin{array}{l}406 \\
31 \overline{8}\end{array}$ & $\left.\begin{array}{l}0.3864 \\
03865\end{array}\right\}$ & 0.3867 & 1.6081 & 0.9 & & & & & $\left.\begin{array}{l}0.3877 \\
03883\end{array}\right\}$ & 0.3883 & 1.6047 & 1.2 \\
\hline $\begin{array}{l}318 \\
51 \overline{2}\end{array}$ & $\left.\begin{array}{l}0.3865 \\
0.3874\end{array}\right)$ & & & & & & & & & & & \\
\hline 423 & $0.3881\}$ & 0.3879 & 1.6057 & 1.0 & 0.3888 & 0.3892 & 1.6031 & 1.1 & 0.3892 & 891 & 2 & \\
\hline $40 \overline{8}$ & 0.3884 & & & & & & & & $0.3900\}$ & 891 & $z$ & .2 \\
\hline $13 \overline{2}$ & 0.4011 & 0.4008 & 1.5795 & 0.3 & & & & & 0.4027 & 0.4024 & 1.5765 & 0.5 \\
\hline 009 & 0.4080 & 0.4080 & 1.5655 & 3.2 & 0.4099 & 0.4100 & 1.5618 & 1.2 & 0.4101 & 0.4102 & 1.5615 & 1.6 \\
\hline 027 & 0.4143 & 0.4141 & 1.5541 & 0.6 & & & & & 0.4162 & 0.4174 & 1.5478 & 1.2 \\
\hline 612 & 0.4192 & 0.4185 & 1.5458 & 1.0 & & & & & 0.4200 & 0.4192 & 1.5445 & 1.3 \\
\hline
\end{tabular}

1. Sonolite from Sono mine, Kyoto Prefecture.

2. Sonolite from Hanawa mine, Iwaté Prefecture.

3. Sonolite from Kusugi mine, Yamaguchi Prefecture.

* A line which may be partly due to rhodochrosite. 


\section{$2 \theta \mathrm{FeK} \alpha$}
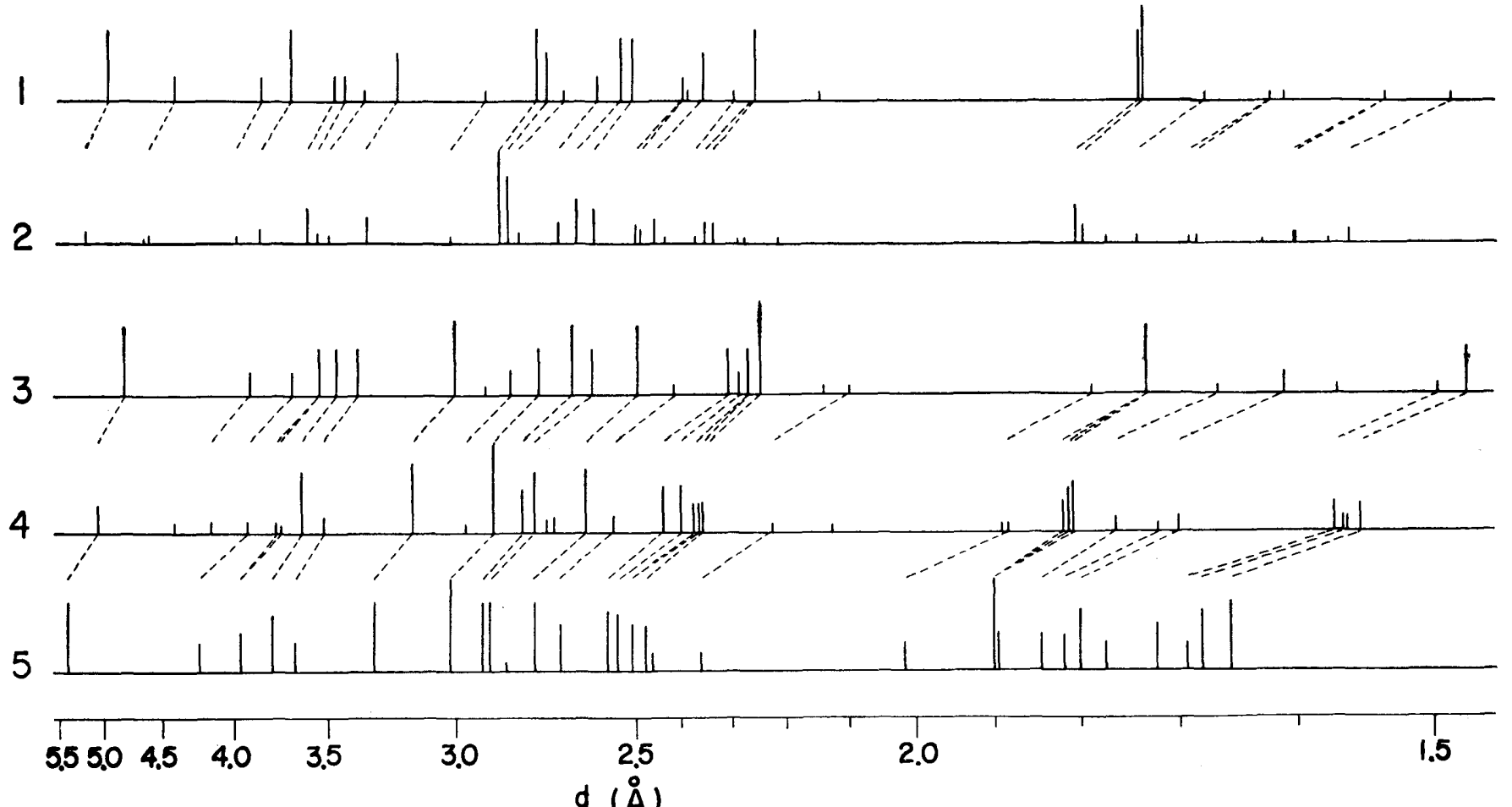

Fig. 6. X-ray diffraction patterns of sonolite, alleghanyite and related minerals

1. Clinohumite from Hämeenkylä, Finland (S S HAMA, 1953).

2. Sonolite from Kusugi mine, Yamaguchi Prefecture (this paper)

3. Chondrodite from Hangelby, Finland (Sahama, 1953).

4. Alleghanyite from Mukaiyama mine, Kyoto Prefecture (this paper)

5. Calcio-chondrodite synthesized (BUCKLE and TAYLOR, 1958). 
The calculated $Q$ values from these parameters are in good agreement with the observed ones as shown in Table 2 .

The powder pattern of sonolite from Taguchi mine was also taken, and its unit cell dimensions are:

$$
\mathrm{a}_{0}=10.62 \AA, \quad \mathrm{b}_{0}=4.87 \AA, \quad \mathrm{c}_{0}=14.23 \AA, \quad \beta=100^{\circ} 36^{\prime} \quad \text { (Taguchi). }
$$

These values are considerably smaller on $\mathrm{a}_{0}$ and $\mathrm{c}_{0}$, and somewhat larger on $\beta$ as compared to those of sonolite of the other localities described above. This may suggest that the mineral from Taguchi mine belongs to an iron and/or magnesiumrich member of sonolite, but this point needs further study.

\section{Chemical Properties and Composition}

Sonolite is decomposed by hydrochloric acid to leave gelatinous silica.

The determinations of each components, except water, carbon dioxide and fluorine, were carried out in the usual manner of chemical analysis. Total water was determined by both the absorption method and the Penfield tube method. The determination of carbon dioxide was made by the absorption method. Fluorine was

Table 4. The chemical analysis of sonolite from Hanawa mine

\begin{tabular}{|c|c|c|c|c|c|c|}
\hline & 1 & 2 & 3 & 4 & & 5 \\
\hline $\mathrm{SiO}_{2}$ & $22.37 \%$ & $0.372 \bar{\jmath}$ & 0.2801 & $3.45)$ & \multirow{3}{*}{4.08} & $23.68 \%$ \\
\hline $\mathrm{TiO}_{2}$ & 0.09 & 0.0011 & 0.0011 & 0.01 & & 0.13 \\
\hline $\mathrm{Al}_{2} \mathrm{O}_{3}$ & 2.56 & 0.0251 & 0.0251 & $0.62)$ & & 3.60 \\
\hline $\mathrm{BaO}$ & nil & & & & & \\
\hline $\mathrm{FeO}$ & 0.93 & 0.0130 & 0.0130 & $0.16)$ & \multirow{3}{*}{9.17} & 1.31 \\
\hline $\mathrm{MnO}$ & 62.01 & 0.8742 & 0.6331 & 7.80 & & 63.22 \\
\hline $\mathrm{MgO}$ & 3.45 & 0.0856 & 0.0856 & 1.05 & & 4.86 \\
\hline $\mathrm{CaO}$ & 0.73 & 0.0130 & 0.0130 & $0.16)$ & \multirow{4}{*}{2.09} & 1.03 \\
\hline $\mathrm{F}$ & 0.21 & 0.0111 & 0.0111 & $0.14)$ & & 0.30 \\
\hline $\mathrm{CO}_{2}$ & 4.53 & 0.1030 & & & & \\
\hline $\mathrm{H}_{2} \mathrm{O}+$ & 3.08 & 0.1710 & 0.0790 & $1.95)$ & & 2.00 \\
\hline \multirow[t]{2}{*}{$\mathrm{H}_{2} \mathrm{O}-$} & 0.30 & & & & & \\
\hline & 100.26 & & & & & 100.13 \\
\hline$-\mathrm{O}=\mathrm{F}$ & 0.09 & & & & & 0.13 \\
\hline Total & 100.17 & & & & & 100.00 \\
\hline
\end{tabular}

1. Sonolite from Hanawa mine. Analyst: M. Yoshinaga. The determination of fluorine was made by $\mathrm{H}$. Matsumoto.

2. Molecular proportion.

3. Less $\mathrm{Mn}_{6} \mathrm{Si}_{4} \mathrm{O}_{10}(\mathrm{OH})_{6}, \mathrm{MnCO}_{3}$ and $\mathrm{Mn}(\mathrm{OH})_{2}$.

4. Number of metal atom.

5. Recalculated to $100 \%$ after deducting impurities. 
determined by the colorimetric microdetermination method with p-dimethylaminoazophenylarsonic acid zirconium lake after KAMATA and ONISHI (1959).

The results of the chemical analyses of sonolites from Hanawa mine and Kusugi mine are given in Tables 4 and 5. Although considerable care was taken in the

Table 5. The chemical analysis of sonolite from Kusugi mine

\begin{tabular}{|c|c|c|c|c|c|c|}
\hline & 1 & 2 & 3 & 4 & & 5 \\
\hline $\mathrm{SiO}_{2}$ & $17.23 \%$ & 0.2869 & 0.2869 & 3.34 & \multirow{3}{*}{3.96} & $22.62 \%$ \\
\hline $\mathrm{TiO}_{2}$ & 0.11 & 0.0014 & 0.0014 & $0.02\}$ & & 0.14 \\
\hline $\mathrm{Al}_{2} \mathrm{O}_{3}$ & 2.62 & 0.0257 & 0.0257 & $0.60)$ & & 3.44 \\
\hline $\mathrm{BaO}$ & nil & & & & \multirow{5}{*}{9.04} & \\
\hline $\mathrm{FeO}$ & 1.39 & 0.0194 & 0.0194 & 0.23 & & 1.82 \\
\hline $\mathrm{MnO}$ & 65.93 & 0.9295 & 0.7204 & 8.39 & & 67.08 \\
\hline $\mathrm{MgO}$ & 0.95 & 0.0236 & 0.0236 & 0.27 & & 1.25 \\
\hline $\mathrm{CaO}$ & 0.70 & 0.0125 & 0.0125 & $0.15)$ & & 0.92 \\
\hline $\mathrm{F}$ & n.d. & & & & & \\
\hline $\mathrm{CO}_{2}$ & 9.20 & 0.2091 & & & & \\
\hline $\mathrm{H}_{2} \mathrm{O}+$ & 2.08 & 0.1155 & 0.1155 & 2.69 & & 2.73 \\
\hline $\mathrm{H}_{2} \mathrm{O}-$ & 0.25 & & & & & \\
\hline Total & 100.46 & & & & & 100.00 \\
\hline
\end{tabular}

1. Sonolite from the Zomeki adit of Kusugi mine. Analyst: M. Yoshinaga.

2. Molecular proportion.

3. Less $\mathrm{MnCO}_{3}$.

4. Number of metal atom.

5. Recalculated to $100 \%$ after deducting impurity.

separation, some amounts of bementite, rhodochrosite and pyrochroite were still contained in the analyzed materials from Hanawa mine, and also some amounts of rhodochrosite in the materials from Kusugi mine, because the separation was very difficult. Therefore, some amounts of $\mathrm{Mn}_{5} \mathrm{Si}_{4} \mathrm{O}_{10}(\mathrm{OH})_{6}, \mathrm{MnCO}_{3}$ and $\mathrm{Mn}(\mathrm{OH})_{2}$ were reduced as impurities from the results of the material from Hanawa mine according to the quantitative estimations by the microscope and by the X-ray examination. On the presumption that sonolite is the manganese analogue of clinohumite $\left(\mathrm{Mg}_{9} \mathrm{Si}_{4}\right.$ $\mathrm{O}_{16}(\mathrm{OH}, \mathrm{F})_{2}$ or $\left.4 \mathrm{Mg}_{2} \mathrm{SiO}_{4} \cdot \mathrm{Mg}(\mathrm{OH}, \mathrm{F})_{2}\right)$, the chemical formula for sonolite from Hanawa mine was calculated on the basis of $18(\mathrm{O}, \mathrm{OH}, \mathrm{F})$ with the following result:

$(\underbrace{\mathrm{Mn}_{7.80} \mathrm{Fe}_{0.16} \mathrm{Mg}_{1.05} \mathrm{Ca}_{0.16}}_{9.17})(\underbrace{\left.\mathrm{Si}_{3.45} \mathrm{Al}_{0.62} \mathrm{Ti}_{0,01}\right)}_{4.08} \underbrace{\mathrm{O}_{15.91}\left[\left(\mathrm{OH}_{1.95}\right) \mathrm{F}_{0.14}\right]}_{18.00}$ (Hanawa).

This formula is in good agreement with the ideal formula $\mathrm{Mn}_{9} \mathrm{Si}_{4} \mathrm{O}_{16}(\mathrm{OH}, \mathrm{F})_{2}$ or $4 \mathrm{Mn}_{2} \mathrm{SiO}_{4} \cdot \mathrm{Mn}(\mathrm{OH}, \mathrm{F})_{2}$.

In the case of the materials from Kusugi mine, $\mathrm{MnCO}_{3}$ was reduced from the results of the analysis and the following formula was obtained: 


$\underbrace{\left(\mathrm{Mn}_{3.89} \mathrm{Fe}_{0.23} \mathrm{Mg}_{0.27} \mathrm{Ca}_{0.15}\right)}_{9.04} \underbrace{\left(\mathrm{Si}_{3.34} \mathrm{Al}_{0.60} \mathrm{Ti}_{0.02}\right)}_{3.96} \underbrace{\mathrm{O}_{15.31}(\mathrm{OH})_{2.69}}_{18.00}$ (Kusugi).

This is also close to the above ideal formula.

\section{Relations of Sonolite to Alleghanyite and to Minerals of the Human Group}

For the original alleghanyite from Bald Knob, Alleghany, North Carolina, the chemical formula $5 \mathrm{MnO} \cdot 2 \mathrm{SiO}_{2}$ was assigned first by Ross and KERR (1932). However, as a result of a later investigation by Rogers (1935) as to the chemical composition and some crystallographic properties, the formula of alleghanyite was expressed as $2 \mathrm{Mn}_{2} \mathrm{SiO}_{4} \cdot \mathrm{Mn}(\mathrm{OH}, \mathrm{F})_{2}$ and it was suggested that this mineral is the manganese analogue of chondrodite. This suggestion was confirmed by SMITH, BANNISTER and HEY (1944) through the X-ray studies of the mineral from Benallt mine, Wales.

Some mineralogical properties of alleghanyite from Mukaiyama mine, Kyoto Prefecture were examined in the same manner to above for comparison with sonolite. Color is pale pink to greyish red. In thin section it is colorless. Hardness is 5.5 . Measurements of specific gravity gave a value of 3.93 . Refractive indices and optic axial angle are as follows:

$$
\alpha=1.762, \quad \beta=1.782, \quad \gamma=1.793, \quad(-) 2 \mathrm{~V}=88^{\circ}
$$

Dispersion is $\rho>v$, weak. The lamellae twinning on (001) is common. The extinction angle $(001) \wedge \mathrm{X}$ is $25^{\circ}$.

The X-ray powder data of the mineral are given in Table 6 together with those of alleghanyite from Bald Knob (LEE, 1955). The pattern was compared with those of chondrodite from Finland (SAHAMA, 1953) and of calcio-chondrodite, the calcium analogue of chondrodite synthesized by BuCKLE and TAYLOR (1958) in Figure 6. Most lines of the pattern of alleghanyite correspond to those of chondrodite and calciochondrodite patterns respectively. Referring to the results on calcio-chondrodite by BUCKLe and TAYLOR (1958), the data of Table 6 for alleghanyite from Mukaiyama mine were indexed and following unit cell dimensions were obtained:

$$
\mathrm{a}_{0}=10.77_{3} \AA, \quad \mathrm{b}_{0}=4.88_{1} \AA, \quad \mathrm{c}_{0}=8.28_{7} \AA, \quad \beta=108^{\circ} 33^{\prime} .
$$

The calculated $Q$ values of Table 5 based on this cell are in good agreement with the observed values. The unit cell dimensions of the mineral from Benallt given by Sмiтн and others (1944) are: $a_{0}=4.83 \AA, \quad b_{0}=10.46 \AA, \quad c_{0}=8.3 \AA, \quad \beta=70^{\circ} 52^{\prime}$. These values were rewritten by Strunz (1957) as follows: $a_{0}=8.3 \AA, \quad b_{0}=4.86 \AA$, $c_{0}=10.46 \AA, \quad \beta=109^{\circ} 8^{\prime}$. An attempt to indexing on referring to these parameters. was not successful because the $\beta$ value are too large.

The properties of sonolite are summarized in Table 7 in comparison with those 
Table 6. X-ray powder data for alleghanyite

\begin{tabular}{|c|c|c|c|c|c|c|}
\hline \multicolumn{5}{|c|}{1} & \multicolumn{2}{|l|}{2} \\
\hline $\mathrm{hkl}$ & $\mathrm{Q}$ calc. & Q obs. & $\mathrm{d}(\AA \AA)$ & I & $\mathrm{d}(\AA)$ & I \\
\hline 220 & 0.0383 & \multirow{2}{*}{0.0387} & \multirow{2}{*}{5.082} & \multirow{2}{*}{3.0} & \multirow{2}{*}{5.00} & \multirow{2}{*}{5} \\
\hline $20 \overline{1}$ & $0.0387\}$ & & & & & \\
\hline 110 & 0.0516 & 0.0513 & 4.413 & 1.0 & 4.37 & $\operatorname{Tr}$ \\
\hline 011 & 0.0582 & 0.0579 & 4.157 & 1.2 & 4.09 & $\operatorname{Tr}$ \\
\hline 002 & 0.0648 & 0.0649 & 3.924 & 1.2 & 3.90 & $\operatorname{Tr}$ \\
\hline 201 & 0.0704 & 0.0704 & 3.768 & 1.0 & & \\
\hline $20 \overline{2}$ & 0.0714 & 0.0715 & 3.741 & 0.7 & 3.73 & $\operatorname{Tr}$ \\
\hline 111 & 0.0757 & 0.0754 & 3.641 & 6.6 & 3.61 & 70 \\
\hline 210 & $0.0803\}$ & \multirow{2}{*}{0.0803} & \multirow{2}{*}{3.529} & \multirow{2}{*}{1.6} & \multirow{2}{*}{3.50} & \multirow{2}{*}{$\operatorname{Tr}$} \\
\hline $21 \overline{1}$ & 0.0807 & & & & & \\
\hline $11 \overline{2}$ & 0.10 .05 & 0.1005 & 3.155 & 7.5 & 3.14 & 80 \\
\hline $21 \overline{2}$ & 0.1134 & 0.1134 & 2.969 & 1.0 & & \\
\hline $31 \overline{1}$ & 0.1207 & 0.1208 & 2.877 & 10 & 2.85 & 90 \\
\hline 310 & 0.1283 & 0.1283 & 2.792 & 4.7 & 2.77 & 40 \\
\hline 112 & 0.1322 & 0.1320 & 2.752 & 6.5 & 2.74 & 40 \\
\hline 202 & 0.1349 & 0.1347 & 2.725 & 1.4 & & \\
\hline $20 \overline{3}$ & 0.1366 & 0.1369 & 2.703 & 1.6 & & \\
\hline $31 \overline{2}$ & $0.1455\}$ & 0.1457 & 2620 & 70 & 261 & 90 \\
\hline 003 & $0.1458\}$ & 0.140 & 2.620 & 7.0 & & \\
\hline 400 & 0.1534 & 0.1535 & 2.552 & 1.7 & 2.53 & $5-$ \\
\hline 311 & 0.1682 & 0.1681 & 2.4393 & 4.8 & 2.42 & 30 \\
\hline $11 \overline{3}$ & 0.1736 & 0.1737 & 2.3996 & 5.0 & 2.39 & 30 \\
\hline 212 & 0.1768 & 0.1771 & 2.3762 & 3.0 & & \\
\hline $21 \overline{3}$ & 0.1786 & 0.1787 & 2.3655 & 3.1 & 2.36 & 30 \\
\hline $41 \overline{1}$ & 0.1799 & 0.1799 & 2.3582 & 3.2 & 2.34 & 30 \\
\hline 401 & 0.2013 & 0.2016 & 2.2269 & 0.8 & & \\
\hline \multirow[t]{3}{*}{113} & 0.2212 & 0.2210 & 2.1271 & 0.7 & 2.12 & $\operatorname{Tr}$ \\
\hline & & & & & 2.04 & $\operatorname{Tr}$ \\
\hline & & & & & 1.93 & $\operatorname{Tr}$ \\
\hline $11 \overline{4}$ & 0.2791 & 0.2795 & 1.8918 & 0.9 & 1.89 & $\operatorname{Tr}$ \\
\hline 402 & $0.2816\}$ & \multirow{2}{*}{0.2815} & \multirow{2}{*}{1.8847} & \multirow{2}{*}{0.9} & \multirow{4}{*}{1.87} & \multirow{4}{*}{$\operatorname{Tr}$} \\
\hline 510 & $0.2816\}$ & & & & & \\
\hline 222 & 0.3028 & 0.3024 & 1.8185 & 3.3 & & \\
\hline $22 \overline{3}$ & 0.3045 & 0.3044 & 1.8125 & 4.8 & & \\
\hline $42 \overline{1}$ & 0.3058 & 0.3055 & 1.8092 & 5.5 & 1.81 & 100 \\
\hline 420 & 0.3213 & 0.3213 & 1.7643 & 1.5 & 1.75 & 10 \\
\hline 511 & 0.3375 & 0.3372 & 1.7219 & 0.9 & 1.71 & 5 \\
\hline 600 & 0.3451 & \multirow{6}{*}{0.3451} & \multirow{6}{*}{1.7022} & \multirow[t]{6}{*}{1.8} & 1.69 & 15 \\
\hline 313 & $0.3454\}$ & & & & & \\
\hline & & & & & 1.65 & $\operatorname{Tr}$ \\
\hline & & & & & 1.64 & 5 \\
\hline & & & & & 1.61 & 5 \\
\hline & & & & & 1.59 & 5 \\
\hline $12 \overline{4}$ & $0.4050\}$ & 0.4051 & 1.5712 & 3.0 & 1.564 & 20 \\
\hline 005 & $0.4050\}$ & & & & & \\
\hline 601 & 0.4089 & 0.4086 & 1.5644 & 1.7 & 1.557 & 20 \\
\hline $60 \overline{4}$ & 0.4141 & 0.4154 & 1.5516 & 3.0 & 1.547 & 20 \\
\hline
\end{tabular}

1. Alleghanyite from Mukaiyama mine, Kyoto Prefecture (this paper).

2. Alleghanyite from Bald Knob, Alleghany County, North Carolina (LEE. 1955). 
Table 7. Physical and optical properties of sonolite and alleghanyite

\begin{tabular}{|c|c|c|c|c|}
\hline & \multicolumn{2}{|c|}{ Sonolite } & \multicolumn{2}{|c|}{ Alleghanyite } \\
\hline & Hanawa & Kusugi & Mukaiyama & Bald Knob* \\
\hline Color & $\begin{array}{l}\text { dull reddish } \\
\text { orange }\end{array}$ & $\begin{array}{l}\text { pale reddish } \\
\text { brown }\end{array}$ & $\begin{array}{l}\text { pale pink to } \\
\text { greyish red }\end{array}$ & $\begin{array}{l}\text { bright pink to } \\
\text { greyish pink }\end{array}$ \\
\hline Hardness & 5.5 & 5.5 & 5.5 & 5.5 \\
\hline $\begin{array}{l}\text { Specific } \\
\text { gravity }\end{array}$ & $\begin{array}{l}3.82 \text { (meas.) } \\
3.97 \text { (calc.) }\end{array}$ & $\begin{array}{l}3.87 \text { (meas.) } \\
4.03 \text { (calc.) }\end{array}$ & 3.93 & 4.020 \\
\hline $\begin{array}{l}\text { Color in thin } \\
\text { section }\end{array}$ & colorless & colorless & colorless & $\begin{array}{l}\text { colorless to } \\
\text { slightly pink }\end{array}$ \\
\hline$\alpha$ & 1.763 & 1.763 & 1.762 & 1.756 \\
\hline$\beta$ & 1.779 & 1.779 & 1.782 & 1.780 \\
\hline$\gamma$ & 1.793 & 1.792 & 1.793 & 1.792 \\
\hline$\gamma-\alpha$ & 0.030 & 0.029 & 0.031 & 0.036 \\
\hline$(-) 2 \mathrm{~V}$ & $75.5^{\circ}-82^{\circ}$ & $70^{\circ}-73^{\circ}$ & $88^{\circ}$ & $72^{\circ}$ \\
\hline Dispersion & $\rho>v$ & $\rho<v$ & $\rho>v$ & $\rho>v$ \\
\hline$(001) \wedge \mathrm{X}$ & $9^{\circ}-10^{\circ}$ & $10^{\circ}$ & $25^{\circ}$ & $\begin{array}{l}22^{\circ} \\
35^{\circ * *}\end{array}$ \\
\hline Twinning & $\begin{array}{l}\text { (001) single, } \\
\text { lamellae }\end{array}$ & (001) lamellae & (001) lamellae & $\begin{array}{l}\text { (001) lamellae, } \\
\text { single }\end{array}$ \\
\hline Crystal system & monoclinic & monoclinic & monoclinic & monoclinic \\
\hline $\mathrm{a}_{0}$ & $10.66_{4} \AA$ & $10.66_{0} \AA$ & $10.77_{3} \AA$ & - \\
\hline $\mathrm{b}_{0}$ & $4.88_{2} \AA$ & $4.87_{8} \AA$ & $4.88_{1} \AA$ & - \\
\hline $\mathrm{c}_{0}$ & $14.29_{9} \AA$ & $14.29_{6} \AA$ & $8.28_{7} \AA$ & - \\
\hline$\beta$ & $100^{\circ} 34^{\prime}$ & $100^{\circ} 34^{\prime}$ & $108^{\circ} 33^{\prime}$ & - \\
\hline
\end{tabular}

* Ross and Kerr (1932)

** According to measurement of Rogers (1935)

of alleghanyites from Mukaiyama mine and also from Bald Knob (Ross and KerR, 1932) (Rogers, 1935). There are close resemblances between their physical and optical properties except the difference in the extinction angle $(001) \wedge \mathrm{X}$.

The optical properties of minerals of the humite group were summarized by LARSEN (1928) and SAHAMA (1938), who showed that it was not possible to distinguish between clinohumite and chondrodite on the basis of their physical and optical properties except the difference in the extinction angle (001) $\wedge \mathrm{X}$. According to LARSEN, the extinction angle $(001) \wedge \mathrm{X}$ are $7^{\circ}-15^{\circ}$ in clinohumite and $22^{\circ}-29^{\circ}$ in chondrodite. On the other hand, the optical studies by SAHAMA indicate that they are $9^{\circ}-15^{\circ}$ in clinohumite and $22^{\circ}-31^{\circ}$ in chondrodite. KöPPEN (1950) also has made reference to the extinction angles of the two minerals and shown that they are $7^{\circ}-$ $15^{\circ}$ in clinohumite and $25-31^{\circ}$ in chondrodite.

To clarify the relation between sonolite and clinohumite as to extinction angle, the extinction angles $(001) \wedge \mathrm{X}$ and the optic axial angles of sonolite and of alleghanyite from various localities were measured on the universal stage. The values 
obtained are given in Table 8 together with the previous values of alleghanyite in literatures. The value of sonolite is variable even in the specimens from the same

Table 8. Optic axial and extinction angles of sonolite and alleghanyite

\begin{tabular}{|c|c|c|c|c|c|}
\hline & Number & Locality & $(-) 2 \mathrm{~V}$ & $(001) \wedge \mathrm{X}$ & Reference \\
\hline \multirow{15}{*}{ 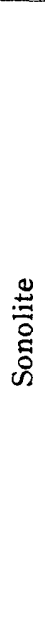 } & 1 & Hanawa, Japan & $75.5^{\circ}$ & $10^{\circ}$ & this paper \\
\hline & 2 & " & 82 & 9 & " \\
\hline & 3 & " & 81 & 10 & " \\
\hline & 4 & Sono, Japan & 88 & 8 & " \\
\hline & 5 & " & 88 & 8.5 & " \\
\hline & 6 & Kusugi, Japan & 70 & 10 & " \\
\hline & 7 & " & 73 & 10 & " \\
\hline & 8 & Kaso, Japan & 78 & 13 & " \\
\hline & 9 & " & 86 & 13 & " \\
\hline & 10 & " & 84 & 11 & " \\
\hline & 11 & Taguchi, Japan & 88 & 15 & " \\
\hline & 12 & " & 86 & 13 & " \\
\hline & 13 & Ioi, Japan & 89 & 12.5 & " \\
\hline & 14 & " & 89 & 13.5 & " \\
\hline & 15 & " & 88 & 12 & " \\
\hline \multirow{10}{*}{ 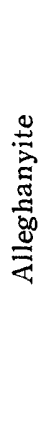 } & 1 & Bald Knob, Alleghany & 72 & 22 & Ross and KERR \\
\hline & 2 & " & 72 & 35 & RoGERS (1935) \\
\hline & 3 & Kaso, Japan & 75 & 27 & YoshIMURA (1938) \\
\hline & 4 & Benallt, Wales & $72-86$ & 28 & Sмitr et al (1944) \\
\hline & 5 & Mukaiyama, Japan & 88 & 25 & this paper \\
\hline & 6 & Sono, Japan & 80 & 22 & " \\
\hline & 7 & Kusugi, Japan & 89 & 23 & " \\
\hline & 8 & Hamayokogawa, Japan & 84 & 24 & " \\
\hline & 9 & " & 86.5 & 24 & " \\
\hline & 10 & Karakizawa, Japan & 84 & 24.5 & " \\
\hline
\end{tabular}

locality. The previous values for clinohumite and chondrodite are also shown in Table 9. The data listed in Table 8 and 9 were plotted in Figure 7 in a graphical form. The range of the optic axial angles of clinohumite was estimated on referring to the data summarized by LARSEN (1928). The number given on each dot is the listed number in Tables 8 and 9 respectively. As evident from Figure 7, the data of the extinction angle in Table 8 and 9 are summarized as follows:

Sonolite: $(001) \wedge \mathrm{X}=8^{\circ}-15^{\circ}$, Clinohumite: $(001) \wedge \mathrm{X}=7^{\circ}-15^{\circ}$.

Alleghanyite: $(001) \wedge \mathrm{X}=22^{\circ}-35^{\circ}$, Chondrodite: $(001) \wedge \mathrm{X}=22^{\circ}-35^{\circ}$.

The range of the extinction angles of sonolite is quite similar that of clinohumite, and differs from that of alleghanyite or chondrodite.

Another important difference between sonolite and alleghanyite is recognized in their unit cell dimensions. As shown in Table $7, \mathrm{c}_{0}$ and $\beta$ values of sonolite differ 
Table 9. Optic axial and extinction angles of clinohumite and chondrodite

\begin{tabular}{|c|c|c|c|c|c|}
\hline & Number & Locality & $(+) 2 \mathrm{~V}$ & $(001)>X$ & Reference \\
\hline \multirow{10}{*}{ 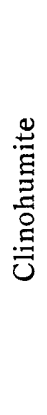 } & 1 & Nordmark, Sweden & $76^{\circ}$ & $12^{\circ}-15^{\circ}$ & LARSEN (1928) \\
\hline & 2 & Tokiwa, Japan & 72 & 9 & WATANABE $(1934)$ \\
\hline & 3 & Hol Kol, Korea & 71 & $9-10$ & WATANABE $(1939)$ \\
\hline & 4 & Inzan, Korea & 70 & 8 & HARADA 1940 \\
\hline & 5 & Tanzawạ, Japan & 71 & $8-9$ & $\mathrm{~K}_{\text {ANO }}(1951)$ \\
\hline & 6 & Hämeenkylä, Finland & 73 & 11 & Sahama (1953) \\
\hline & 7 & Ojamo, Lohja, Finland & 73 & 9 & " \\
\hline & 8 & Bhandara, India & 76 & 9 & Muthuswami (1958) \\
\hline & 9 & Mizunashi, Japan & $70.5,71$ & 9,10 & SozdKI (1959) \\
\hline & 10 & Aldan, East Siberia & 69 & 7 & MarakUShev (1959) \\
\hline \multirow{12}{*}{ 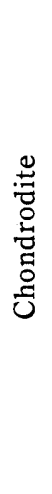 } & 1 & Mansjö, Sweden & 72 & 26 & v. EokERmann (1922) \\
\hline & 2 & Christiansand, Norway & $85-90$ & 27 & BARTH (1924) \\
\hline & 3 & Nordmark, Sweden & 80 & 27 & LARSEN (1928) \\
\hline & 4 & Hangelby, Sibbo, Finland & 72 & 26 & Sahama (1953) \\
\hline & 5 & Kafveltorp, Sweden & 72 & 22 & " \\
\hline & 6 & Sparta, Sussex Co., N.J. & 72 & 26 & " \\
\hline & 7 & Eden, Orange Co., N.Y. & 73 & 26 & " \\
\hline & 8 & Hermala, Lohja, Finland & 77 & 27 & " \\
\hline & 9 & Franklin, N.J. & 80 & 28 & " \\
\hline & 10 & Tilly Foster, Brewster, N.Y. & 75 & 24 & " \\
\hline & 11 & Kafveltorp, Sweden & 79 & 31 & " \\
\hline & 12 & Kamioka, Japan & 75 & 35 & Nozawa (1952) \\
\hline
\end{tabular}

distinctly from those of alleghanyite, although $a_{0}$ and $b_{0}$ values of the two minerals are in close resemblance.

TAYLOR and WEST $(1928,1929)$ investigated the crystal structures of the minerals of the humite group and showed that the interesting morphotropic relationships exist between their structures. According to them, the four minerals of this group possess a slab structure, related to that of forsterite, with alternating layers of forsterite and brucite-sellaite compositions lying parallel to (001). The stoichiometric ratio of $\mathrm{Mg}_{2} \mathrm{SiO}_{4}$ layers to $\mathrm{Mg}(\mathrm{OH}, \mathrm{F})_{2}$ layers varies from 1:1 for norbergite to $1: 4$ for clinohumite. The data of forsterite and four minerals of the humite group summarized by TAYLOR and WEST are shown in the upper part of Table 10, where $a_{0}$ and $b_{0}$ dimensions given by them are replaced each other for convenience sake. $a_{0}$ and $b_{0}$ values of the members of the humite group show relatively little variation and are almost identical with those of forsterite, but $c_{0}$ values vary systematically with the change of composition of the olivine and brucite-sellaite layers of each mineral.

The similar relationships are recognizable among sonolite and related minerals, too. As shown in the middle part of Table 10, $a_{0}$ and $b_{0}$ values of sonolite and 


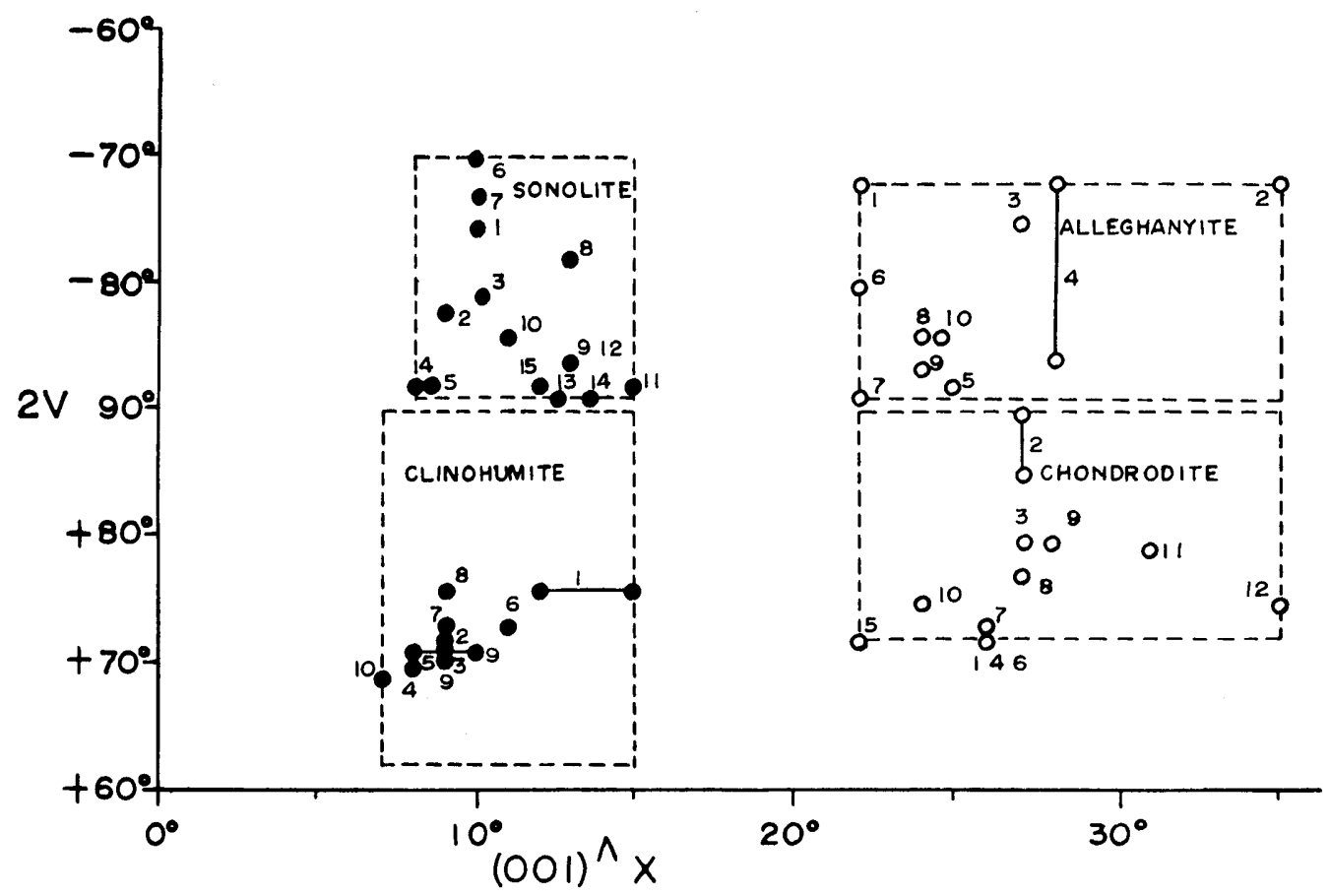

Fig. 7. Extinction angle $(001) \wedge \mathrm{X}$ for sonolite, alleghanyite, clinohumite and chondrodite plotted against optic axial angle

Table 10. Unit cell dimensions of the minerals of the humite group and related minerals

\begin{tabular}{|c|c|c|c|c|c|c|c|}
\hline Mineral name & Chemical formula & $\mathrm{a}_{0}(\AA)$ & $\mathrm{b}_{0}(\AA)$ & $c_{0}(\AA)$ & $\beta$ & $\mathrm{d}_{001}(\AA)$ & $\begin{array}{l}\text { Crystal } \\
\text { system** }\end{array}$ \\
\hline Forsterite & $\mathrm{Mg}_{2} \mathrm{SiO}_{4}$ & 10.21 & 4.755 & 5.98 & & $4 \times 1.495$ & ortho. \\
\hline Norbergite & $\mathrm{Mg}_{2} \mathrm{SiO}_{4} \cdot \mathrm{Mg}(\mathrm{OH}, \mathrm{F})_{2}$ & 10.20 & 4.70 & 8.72 & & $6 \times 1.453$ & ortho. \\
\hline Chondrodite & $2 \mathrm{Mg}_{2} \mathrm{SiO}_{4} \cdot \mathrm{Mg}(\mathrm{OH}, \mathrm{F})_{2}$ & 10.27 & 4.733 & 7.87 & $109^{\circ} 2^{\prime}$ & $5 \times 1.488$ & mono. \\
\hline Humite & $3 \mathrm{Mg}_{2} \mathrm{SiO}_{4} \cdot \mathrm{Mg}(\mathrm{OH}, \mathrm{F})_{2}$ & 10.23 & 4.738 & 20.86 & & $14 \times 1.490$ & ortho. \\
\hline Clinohumite & $4 \mathrm{Mg}_{2} \mathrm{SiO}_{4} \cdot \mathrm{Mg}(\mathrm{OH}, \mathrm{F})_{2}$ & 10.27 & 4.745 & 13.68 & $100^{\circ} 50^{\prime}$ & $9 \times 1.492$ & mono. \\
\hline Tephroite & $\mathrm{Mn}_{2} \mathrm{SiO}_{4}$ & 10.64 & 4.87 & 6.23 & & $4 \times 1.558$ & ortho. \\
\hline- & $\mathrm{Mn}_{2} \mathrm{SiO}_{4} \cdot \mathrm{Mn}(\mathrm{OH}, \mathrm{F})_{2}$ & 10.64 & 4.87 & 9.35 & & $6 \times 1.558$ & ortho. \\
\hline Alleghanyite & $2 \mathrm{Mn}_{2} \mathrm{SiO}_{4} \cdot \mathrm{Mn}(\mathrm{OH}, \mathrm{F})_{2}$ & 10.77 & 4.88 & 8.29 & $108^{\circ} 33^{\prime}$ & $5 \times 1.571$ & mono. \\
\hline & $3 \mathrm{Mn}_{2} \mathrm{SiO}_{4} \cdot \mathrm{Mn}(\mathrm{OH}, \mathrm{F})_{2}$ & 10.64 & 4.87 & 21.81 & & $14 \times 1.558$ & ortho. \\
\hline Sonolite & $4 \mathrm{Mn}_{2} \mathrm{SiO}_{4} \cdot \mathrm{Mn}(\mathrm{OH}, \mathrm{F})_{2}$ & 10.66 & 4.88 & 14.30 & $100^{\circ} 34^{\prime}$ & $9 \times 1.562$ & mono. \\
\hline r-Dicalcium silicate & $\mathrm{Ca}_{2} \mathrm{SiO}_{4}$ & 11.28 & 5.06 & 6.78 & & $4 \times 1.695$ & ortho. \\
\hline- & $\mathrm{Ca}_{2} \mathrm{SiO}_{4} \cdot \mathrm{Ca}(\mathrm{OH})_{2}$ & 11.28 & 5.05 & 10.17 & & $6 \times 1.695$ & ortho. \\
\hline Calcio-chondrodite & $2 \mathrm{Ca}_{2} \mathrm{SiO}_{4} \cdot \mathrm{Ca}(\mathrm{OH})_{2}$ & 11.28 & 5.05 & 8.94 & $108^{\circ} 24^{\prime}$ & $5 \times 1.697$ & mono. \\
\hline 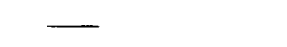 & $3 \mathrm{Ca}_{2} \mathrm{SiO}_{4} \cdot \mathrm{Ca}(\mathrm{OH})_{2}$ & 11.28 & 5.05 & 23.73 & & $14 \times 1.695$ & ortho. \\
\hline & $4 \mathrm{Ca}_{2} \mathrm{SiO}_{4} \cdot \mathrm{Ca}(\mathrm{OH})_{2}$ & 11.28 & 5.05 & 15.52 & $100^{\circ} 30^{\prime}$ & $9 \times 1.696$ & \\
\hline
\end{tabular}

* ortho.: orthorhombic, Pnma, $Z=4$. mono.: monoclinic, $\mathrm{P} 2 / \mathrm{a}, \mathrm{Z}=2$, 
alleghanyite are close to those of tephroite which are given by O'DANIEL and Tscheischwili (1943), and the systematic variation in the $c_{0}$ and $d_{001}$ values is correlated to that in the humite group.

If we assume that these morphotropic relationships can be applied to possible manganese analogues of norbergite and humite which are so far unknown*, the unit cell dimensions and the crystal systems of them would be expected as given in Table 10.

BUCKLE and TAYLOR (1958) have calculated the unit cell dimensions of calcium analogues of members of the humite group, which are not yet known except calciochondrodite. Their data are shown in the lower part of Table 10.

As mentioned above, the new mineral sonolite is evidently the manganese analogue of clinohumite, and the relationship of sonolite to alleghanyite is especially close because these minerals represent morphotropic forms similar to the corresponding minerals of the humite group. These two minerals, therefore, are inferred to form a group corresponding to humite group.

\section{Acknowledgements}

The writer wishes to express his sincere thanks to Professor Toyofumi Yoshimura of Kyushu University for his kind guidance, offer of the samples from many localities, and critical reading of this paper in manuscript, to Assistant Professor Haruo SHIROzU of Kyushu University for his kind advice and his cordial offer of thin sections of the samples from Ioi mine, and to Dr. Hatao Marsumoto of Kumamoto University for his courtesy in analysis of fluorine. Also hearty thanks are subjected to Professor Takeo Watanabe of University of Tokyo for his valuable suggestions, and to Dr. Fumitoshi Hirowatari of the Geological Survey of Japan, Drs. Yukio MatsuMoto and Hitoshi Momor, and Mrs. Eiko YoshinaGa of Kyushu University for their discussion throughout this study. Thanks are also due to Miss Chizuko Okamura for their help in preparing the typescript.

This work was financed by the Grant in Aid for Scientific Researches from the Ministry of Education, Japan.

* Hodgkinsonite $\left(\mathrm{Zn}_{2} \mathrm{SiO}_{4} \cdot \mathrm{Mn}(\mathrm{OH})_{2}\right)$ and leucophenicite $\left(3 \mathrm{Mn}_{2} \mathrm{SiO}_{4} \cdot \mathrm{Mn}(\mathrm{OH})_{2}\right)$ are minerals corresponding stoichiometrically to norbergite and humite respectively. These minerals are monoclinic (Penfield and Warren, 1899) (Palache and Sohaller, 1914) (Patache, 1935) (Rentzeperis, 1958). In addition hodgkinsonite is not the manganese analogue of norbergite because this mineral is a double salt of willemite and pyrochroite compositions. It is beyond this paper to discuss the manganese analogues of all members of the humite group. 


\section{References}

BARTh, T. (1924): On contact minerals from the Pre-Cambrian in southern Norway. Norsk Geol. Tidskr., 8, 94-96.

BuckLe, E. R. and TAYLOR, H. F. W. (1958): A calcium analogue of chondrodite. Am. Mineral., 43. 818-823.

von Eckermann, H. (1922): The rocks and contact minerals of the Mansjo Mountain. Geol. Fören. Förhand1., 44, 203-409.

Harada Zyunpei and Ishibashi, Masao (1940): Clinohumite from Inzan, Heian-nando, Korea (in Japanese). Jour. Jap. Assoc. Min. Petr. Econ. Geol., 24, 271-276.

Kamads, Masaakira and Onishi, Tomio (1959): New colorimetric microdetermination of fluoride with p-dimethylaminoazophenylarsonic acid zirconium lake. Sci. Rep. Kagoshima Univ., 8, 93-100.

Kano, Hiroshi (1951): Clinohumite and its paragenesis from Tanzawa mountainlands, Kanagawa Pref. (in Japanese). Jour. Jap. Assoc. Min. Petr. Econ. Geol., 35, 116-122.

Köppen, N. (1950): Gesetzmässige Verwachsung von synthetischem Phlogopit mit Mineralien der Humitgruppe. Neues Jahrb. Min. Geol., Abhandl., Abt. A, 80, 343-374.

Larsen, E. S. (1928): The optical properties of the humite group. Am. Mineral., 8, 351-359.

LEe, D. E. (1955): Mineralogy of some Japanese manganese ores. Stanford Univ. Publ. Univ. Ser. Geol. Sci., 5, 1-64.

Marakushev, A. A. (1959): Hypogen borates in Cambrian dolomites of the Aldan Shield (in Russian). Doklady Acad. Sci. USSR, 124, 915-918.

Muthuswami, T. N. (1958): Clinohumite, Sausar series, Bhandara District, India. Proc. Indian Acad. Sci., 48A, 9-28.

Nozawa, Tamotsu (1952): Chondrodite from Kamioka, Japan (in Japanese). Jour. Jap. Assoc. Min. Petr. Econ. Geol., 36, 176-185.

O'Daniel, H. and Tscheischwili, L. (1943): Strukturuntersuchungen an Tephroit $\mathrm{Mn}_{2} \mathrm{SiO}_{4}$, Glaukochroit $(\mathrm{Mn}, \mathrm{Ca})_{2} \mathrm{SiO}_{4}$ und Willemit $\mathrm{Zn}_{2} \mathrm{SiO}_{4}$ von Franklin Furnace. Zeit. :Krist., 105, 273-278.

Penfield S. L. and Warren, C. E. (1899): Some new minerals from the zinc mines at Franklin, N.J., and concerning the chemical composition of ganomalite. Am. Jour. Sci., 8, 339353.

Palache, C. and Schaller, W. T. (1914): Hodgkinsonit, ein neues Mineral von Franklin Furnace, N. J. Zeit. Krist. Min., 53, 529-532.

Palache, C. (1935): The minerals of Franklin and Sterling Hill, Sussex County, New Jersey. U.S. Geol. Surv. Prof. pap., 180, 1-135.

Rentzeperis, P. J. (1958): The unit cell and space group of hodgkinsonite. Acta Cryst., 11, 448.

Rogers, A. F. (1935): The chemical formula and crystal system of alleghanyite. Am. Mineral., 20, 25-35.

Ross C. S. and Kerr, P. F. (1932): The manganese minerals of vein near Bald Knob, North Carolina. Am. Mineral., 17, 1-18.

Sahama, Th. G. (1953): Mineralogy of the humite group. Ann. Acad. Sci. Fennicae, III. Geol. Geogr., 31, 1-50.

Shirozo, Haruo (1949a): On the manganese deposits of the Ioi mine, Shiga Prefecture, with special reference to hausmannite (in Japanese). Jour. Geol. Soc. Japan, 55, 1-7.

(1949b): Hausmannite from the Ioi mine, Shiga Prefecture, Japan. Mem. Fac. Sci. Kyushu Univ., Ser. D, 3, 71-76.

Suith, W. C., Bannister, F. A. and Hey, M. H. (1944): Banalsite, a new barium-felspar from Wales. Min. Mag., 27, 33-46.

Stronz, H. (1957): Mineralogische Tabellen. Akademische Verlagsgesellschaft Geest \& Portig K.-G., Leipzig.

Sozori, Mamoru (1959): Metasomatic replacement of crystalline limestones found in the 
Mizunashi District, western part of the Hida metamorphic zone (in Japanese). Jour. Geol. Soc. Japan, 65, 184-195.

TAYLOR, W. H. and West, J. (1928): The crystal structure of the chondrodite series. Proc. Roy. Soc. London, A, 117, 517-532.

and

(1929): The structure of norbergite. Zeit. Krist., 70, 461-474.

Watanabe, Takeo (1934): On the contact minerals from Tokiwa, Nagano Prefecture, Japan.

(3) Clinohumite and pargasite (in Japanese). Jour. Geol. Soc. Japan, 41, 457-459.

(1939): Kotoit, ein neues gesteinsbildendes Magnesiumborat. Min. Petr. Mitt., 50, $441-463$.

Yoseimura, Toyofumi (1938): Geology and ore deposit of Kaso mine, Tochigi Prefecture, with special reference to mineral paragenesis (in Japanese). Jour. Geol. Soc. Japan, 45, 91-204. - (1939): Studies on the minerals from the manganese deposit of the Kaso mine, Japan. Jour. Fac. Sci., Hokkaido Imp. Univ., Ser. IV, 4, 313-452.

and Moмог, Hitoshi (1961): Dannemorite from Zomeki, Yamaguchi Prefecture, Japan (in Japanese). Sci. Rep. Fac. Sci., Kyushu Univ., 5, 99-110. 
Mayumi YoshinAGA

Sonolite, a New Manganese Silicate Mineral

Plates 1-3 
Plate 1 


\section{Explanation of Plate 1}

Figs. 1-2. Photomicrographs of sonolite-bearing ore from Hanawa mine, Iwaté Prefecture. S: sonolite, R: rhodochrosite. Fig. 1. Polarizer only. Fig. 2. Crossed nicols. $\times 125$.

Fig. 3. Photomicrograph of manganosite-bearing sonolite ore from the east part of the minus 14th level of Kaso mine, Tochigi Prefecture. Radial developments of partings are seen around manganosite grains. S: sonolite, M: manganosite. Polarizer only. $\times 135$.

Fig. 4. Photomicrograph of sonolite-bearing ore from the 3rd level of Taguchi mine, Aichi Prefecture. Round crystals of sonolite with partings are disseminated in the mosaic of rhodochrosite. S: sonolite, R: rhodochrosite, A: alabandite. Polarizer only. $\times 36$. 

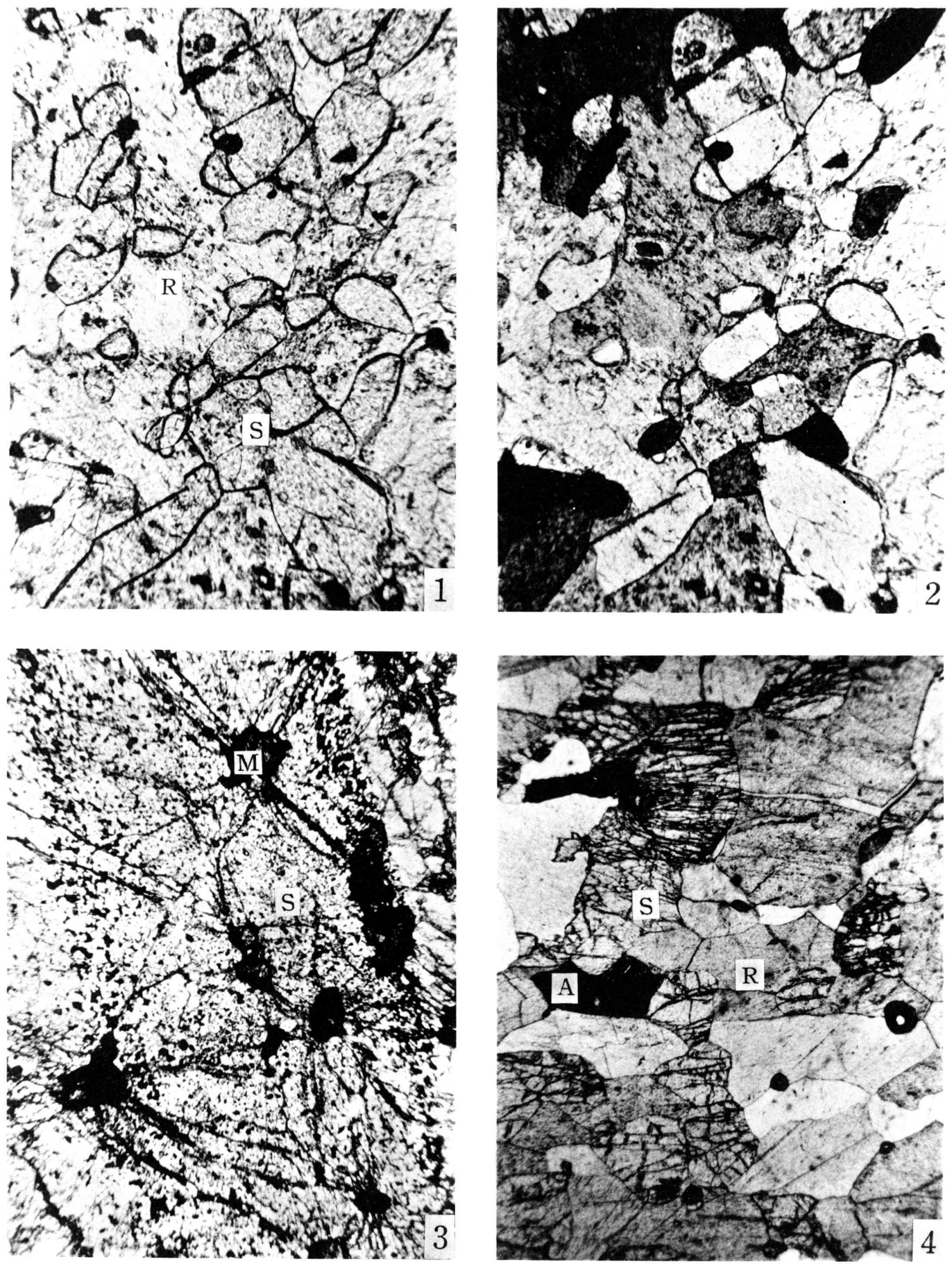
Plate 2 


\section{Explanation of Plate 2}

Fig. 5. Polished hand specimen of sonolite-bearing ore from the 1st adit of Sono mine, Kyoto Prefecture. S: sonolite, $\mathrm{T}$ : tephroite, $\mathrm{R}$ : rhodochrosite and rhodonite, $\mathrm{P}$ : pyroxmangite and neotocite. $\times 1$.

Figs. 6-7. Photomicrographs of sonolite-bearing ore from the Zomeki adit of Kusugi mine, Yamaguchi Prefecture. Sonolite and rhodochrosite show the sutured mosaic texture. S: sonolite, R: rhodochrosite, G: galaxite. Fig. 6. Polarizer only. Fig. 7. Crossed nicols. $\times 36$. 

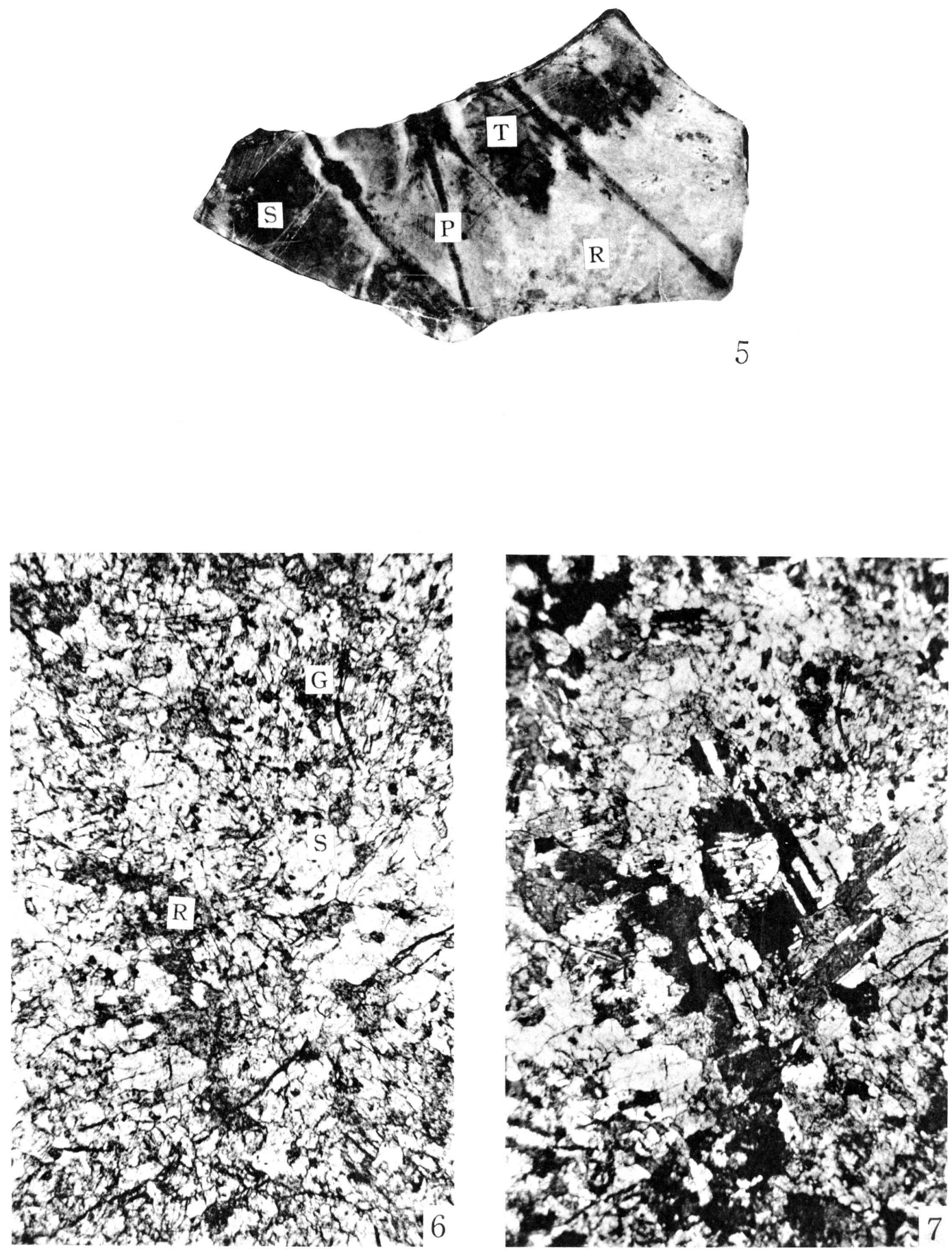

M. Yoshinaga: Sonolite, a New Manganese Silcate Mineral 
Plate 3 


\section{Explanation of Plate 3}

Figs. 8-9. Photomicrographs of sonolite from Hanawa mine, Iwaté Prefecture, showing lamellae and single twinnings. Crossed nicols. Fig. $8 . \times 200$. Fig. $9 . \times 125$.

Figs. 10-12. Photomicrographs of sonolite from the Zomeki adit of Kusugi mine, Yamaguchi Prefecture, showing the symmetrical extinction on the lamellae twinning normal to $Z$. Crossed nicols. $\times 115$. 

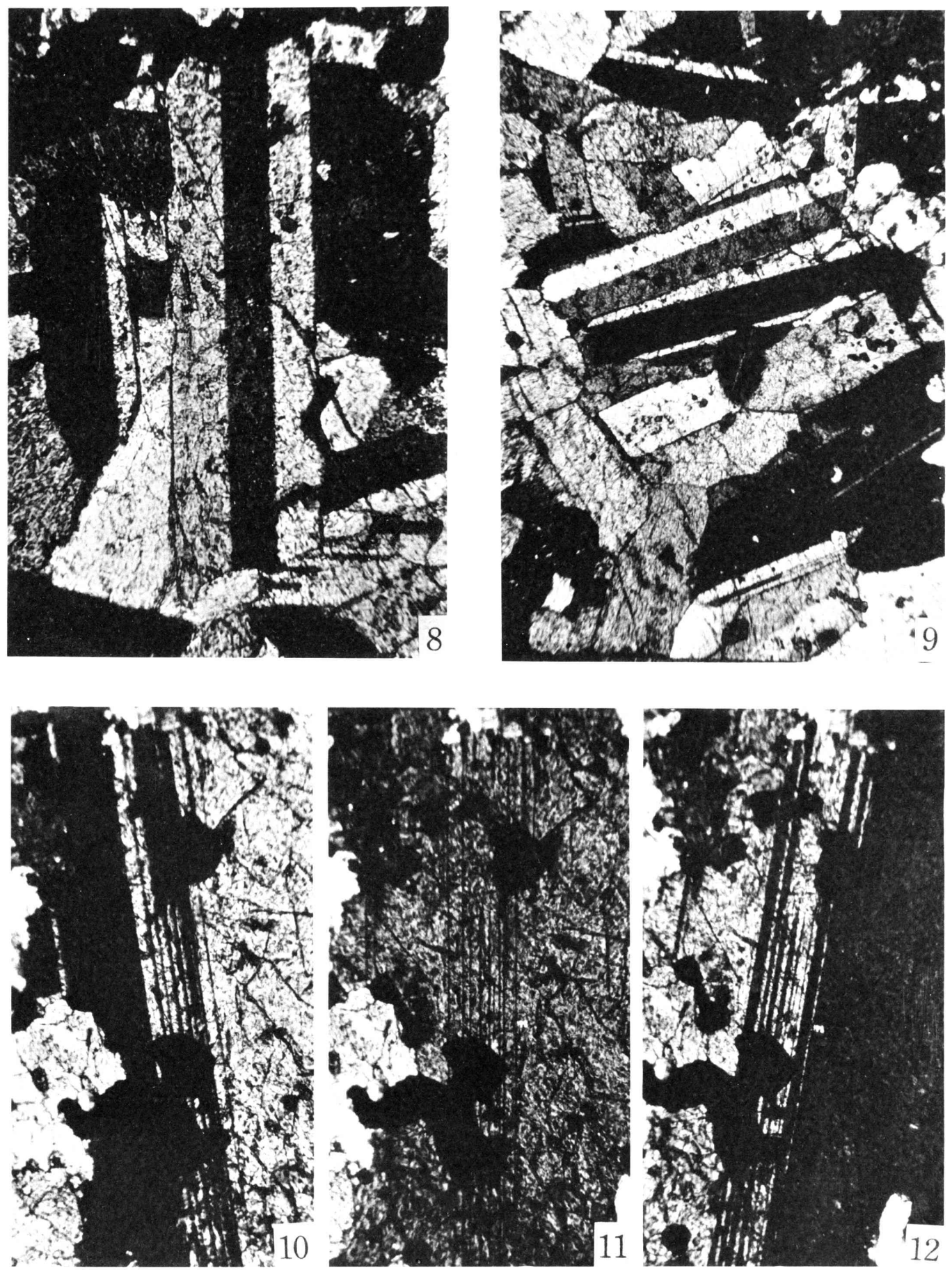